NBER WORKING PAPER SERIES

\title{
WHAT IS THE PRICE OF HUBRIS? \\ USING TAKEOVER BATTLES TO INFER \\ OVERPAYMENTS AND SYNERGIES
}

\author{
Pekka Hietala \\ Steven N. Kaplan \\ David T. Robinson
}

Working Paper 9264

http://www.nber.org/papers/w9264

\author{
NATIONAL BUREAU OF ECONOMIC RESEARCH \\ 1050 Massachusetts Avenue \\ Cambridge, MA 02138 \\ October 2002
}

We would like to thank Rob Gertner for suggesting that this acquisition would have theoretical interest. Erik Stafford provided helpful comments. The views expressed herein are those of the authors and not necessarily those of the National Bureau of Economic Research.

(C) 2002 by Pekka Hietala, Steven N. Kaplan, and David T. Robinson. All rights reserved. Short sections of text, not to exceed two paragraphs, may be quoted without explicit permission provided that full credit, including $(\mathrm{C}$ notice, is given to the source. 
What is the Price of Hubris? Using Takeover Battles to Infer Overpayments and Synergies Pekka Hietala, Steven N. Kaplan, and David T. Robinson

NBER Working Paper No. 9264

October 2002

\begin{abstract}
$\underline{\text { ABSTRACT }}$
We present a framework for determining the information that can be extracted from stock prices around takeover contests. In only two types of cases is it theoretically possible to use stock price movements to infer bidder overpayment and relative synergies. The takeover contest for Paramount in 1994 illustrates one of these generic cases. We estimate that Viacom, the "winning" bidder, overpaid for Paramount by more than $\$ 2$ billion. This occurred despite the fact that Viacom's CEO owned roughly $3 / 4$ of Viacom. These results are consistent with managerial overconfidence and/or large private benefits, but not with the traditional agency-based incentive problem.
\end{abstract}

\author{
Pekka Hietala \\ Insead \\ Boulevard de Constance \\ 77305 Fontainebleau \\ Cedex, France \\ Steven Kaplan \\ University of Chicago Graduate School of Business \\ 1101 East $58^{\text {th }}$ Street \\ Chicago, IL 60637 \\ and NBER \\ steven.kaplan@gsb.uchicago.edu \\ David Robinson \\ Columbia University \\ 3022 Broadway \\ Uris Hall 414 \\ New York, NY 10027
}


When a merger is announced, three different pieces of information affect the stock prices of the target and bidder. The announcement reveals information about the potential synergies arising from the combination, the stand-alone value of the firms involved in the merger, and, how the value will be split between the target and the bidder(s). In general, it is not possible to distinguish among these three effects in a particular takeover contest. For example, if the announcement reveals favorable (unfavorable) information about the target and bidder, the combined change in bidder and target stock values will exceed (not exceed) the synergies arising from the merger. ${ }^{1}$ Similarly, if the bid reveals favorable (unfavorable) news about the stand-alone value of the bidder, the change in bidder stock value will overstate (understate) the benefit of the transaction to the bidder. ${ }^{2}$

This paper develops and applies a classification scheme that identifies those situations in which it is potentially possible to disentangle the sources of price changes. In the first part of the paper, we identify two generic cases in which synergy, overpayment, and information effects can be disentangled to solve for the estimated overpayment by the bidder. One occurs when the acquisition is not consummated; the other occurs when the acquisition is a takeover contest that includes exactly two bidders. We also discuss the additional (inf ormation) conditions that must be satisfied in practice to be able to disentangle the different effects. Even among the generic cases we identify, we point out that most takeovers will not satisfy the necessary conditions.

In the second part of this paper, we analyze the takeover contest for Paramount that began in the fall of 1993 and ended in the winter of 1994. This contest (1) is representative of one of the generic cases and (2) comes close to satisfying the required information conditions. The Paramount contest involved exactly two bidders: QVC, led by Barry Diller; and Viacom, led by Sumner Redstone. The unusual structure of the contest allows us to estimate bidder overpayments, relative synergies, and information effects.

\footnotetext{
${ }_{1}^{1}$ See, for example, Bradley, Desai and Kim (1988), Jensen and Ruback (1983), and Roll (1986).

${ }^{2}$ For example, offers financed by the bidder's stock may signal that the stock is over-valued (Franks, Harris, and Titman (1991)).
} 
We use our framework to calculate that the market estimated that Viacom, the eventual "winner" of the takeover battle, overpaid by more than $\$ 2$ billion when it agreed to purchase Paramount in a $\$ 9.2$ billion acquisition in February 1994. The market estimates appear to be reliable in that market prices did not revert in the three years following the acquisition. This overpayment occurred despite the fact that Sumner Redstone, the CEO of Viacom, owned more than 75\% of the Viacom's cash flow and voting rights.

These results have two possible (and not mutually exclusive) interpretations. The first is that Redstone's beliefs were very different from those of the market. The unwillingness to revise those beliefs in light of the market reaction is strongly consistent with the argument in Roll (1986) that "bidding firms infected by hubris simply pay too much for their targets," as well as papers that stress managerial overconfidence such as Heaton (2002) and Malmendier and Tate (2002).

The second interpretation is that Redstone received large private (and non-pecuniary) benefits from the acquisition. Perhaps he wanted to be the "king of all media." This is strongly consistent with theories in which private benefits drive managerial decision making over and above pecuniary incentives. The important point here is that neither interpretation is consistent with the traditional agency or incentive problem because Redstone controlled such a large fraction of Viacom's cash flow rights. Our analysis indicates that the combination of hubris and private benefits exceeded $\$ 1.5$ billion.

This paper contributes to a large literature in corporate finance that studies the information and value effects of mergers. That literature is too large to survey here. ${ }^{3}$ The papers closest to ours are Bhagat, Hirshleifer and Noah (2001), Fuller, Netter and Stegemoller (2002), and Schurman (1999). Bhagat et al. (2001) estimate overpayments and synergies using movements in the bidder's and target's stock prices around an intervening offer from another firm. They identify their empirical analysis by using ex post data (the sample average) to estimate the ex ante probabilities of success for initial and subsequent bidders and the expected price that a winning bidder will have to pay. With these assumptions, they find that acquisitions are expected to be value increasing overall, but that bidders do 
not gain on average. Fuller et al. (2002) estimate bidder returns for frequent or serial acquirers. They argue that this reduces the amount of information about the bidder that is revealed in any particular acquisition. Schurman (1999) uses a related intervention technique to estimate proposed overpayments in acquisitions that were rejected by anti-trust authorities. Consistent with our results, he finds that bidders who suffer losses at takeover announcements do so primarily due to overpayment. Our empirical analysis differs from those in those papers in that we obtain direct estimates of overpayment and relative synergies for one particular transaction.

Our paper also illustrates the issues raised by Bebchuk and Hart (2001) who present a model to study the relationship between pre-voting market prices and shareholder tender and voting decisions in control contests.

The paper proceeds as follows. Section I introduces the symbols and definitions used throughout the paper, and sets up the basic problem that we study. Section II derives those generic takeover situations in which it is potentially possible to estimate how much the bidder overpays for the target. We also discuss the additional conditions necessary to generate these estimates. Section III presents the clinical analysis of the paper. We detail the sequence of events that led to the Paramount auction, and analyze the market reactions to developments as they occurred. Section IV applies the methodology from sections I and II to the Paramount takeover contest, and solves for the market's estimates of the two bidders' information effects, overpayments and relative synergies with Paramount. Section V concludes.

\section{I.. The Analytical Framework}

In this section, we analyze generic acquisition contests between $\mathrm{N}$ potential acquirers and one target. Let the acquirers be denoted by A, B, C,..., the target, T. To simplify the analysis, we describe a takeover contest with four distinct points in time:

\footnotetext{
${ }^{3}$ For a recent survey, see Andrade, Mitchell and Stafford (2001).
} 
- Time $\mathbf{0}$ denotes a time before the takeover contest has started. The market prices of the potential acquirers and the target reflect the market's estimates of the companies stand alone values without any information about the coming takeover contest.

- Time 1 denotes the time when the takeover contest begins by at least one of the potential acquirers submitting an initial bid. The market prices of the potential acquirers and the target reflect the new information in a manner consistent with the market's consensus. In our analysis we do not use these prices.

- Time 2 denotes the time when all the potential acquirers have submitted their final offers (or, more importantly what the market believes are the final offers). We assume that the market prices at this point reflect (a) the market's valuations of different possible combinations, (b) the market's updated stand-alone valuations of individual companies (updated for the information possibly revealed by the various bids) and (c) the market's assessments of the winning probabilities for each bid (denoted $\theta_{\mathrm{t}}^{\mathrm{I}}$ for firm $\mathrm{I}$ ). W will consider the case in which the sum of the winning probabilities is one as well as the case in which the sum is less than one.

- Time 3 denotes when the board of directors (or the shareholders) announces the outcome of the contest. As mentioned above, we will consider the case in which the outcome has to be an acquisition by one of the acquirers as well as the case in which it is possible that the board announces that the takeover contest is over and the target will continue to operate independently.

Market values at time 3 reflect the final outcome and are denoted as follows. Let $\mathrm{I}^{\mathrm{J}}$ represent the value of firm I if firm $\mathrm{J}$ wins control of the target, T. For instance, $\mathrm{A}^{\mathrm{A}}, \mathrm{B}^{\mathrm{B}}, \mathrm{C}^{\mathrm{C}}, \ldots$, denote the value of the particular acquirer if it is the winner of the takeover contest. These values reflect the market's estimates of the synergies, readjusted stand-alone values, as well as the winner's final offer. Likewise, $\mathrm{A}^{\mathrm{B}}$ represents the value of firm A if firm B wins control of the target.

Next, let $\mathrm{A}^{\mathrm{N}}, \mathrm{B}^{\mathrm{N}}, \mathrm{C}^{\mathrm{N}}, \ldots$, and $\mathrm{T}^{\mathrm{N}}$, represent the market values of firms $\mathrm{A}, \mathrm{B}, \mathrm{C}, \ldots, \mathrm{T}$, if no acquisition takes place. These values reflect the market's updated stand-alone values of the firms. Finally, the target's market value in the case of a successful acquisition by firm $\mathrm{I}$ is denoted $\mathrm{O}^{\mathrm{I}}\left(\mathrm{I}^{\mathrm{I}}\right)$. For example, $\mathrm{O}^{\mathrm{A}}\left(\mathrm{A}^{\mathrm{A}}\right)$ refers to the value of acquirer A's final offer, which can be a function of the acquirer's share price if the offer includes securities of the acquirer. 


\section{A. Defining the Sources of Value Change}

We can now define the market's estimates of the synergies in the acquisition, the overpayment by the acquirer, and the information revealed about the stand-alone values of the various acquirers and the target. Assume that firm A ultimately wins control of the target. Then the total value change accruing to the successful bidder and target is $\left[\mathrm{A}^{\mathrm{A}}-\mathrm{A}_{0}\right]+\left[\mathrm{O}^{\mathrm{A}}-\mathrm{T}_{0}\right]$, which can be rewritten as:

$$
\left[\mathrm{A}^{\mathrm{A}}-\mathrm{A}_{0}\right]+\left[\mathrm{O}^{\mathrm{A}}-\mathrm{T}_{0}\right]=\left[\mathrm{A}^{\mathrm{A}}-\mathrm{A}^{\mathrm{N}}\right]+\left[\mathrm{O}^{\mathrm{A}}-\mathrm{T}^{\mathrm{N}}\right]+\left[\mathrm{A}^{\mathrm{N}}-\mathrm{A}_{0}\right]+\left[\mathrm{T}^{\mathrm{N}}-\mathrm{T}_{0}\right]
$$

Each of the four bracketed terms on the right-hand side of equation 0 carries a distinct interpretation. These can be summarized as follows:
(1A) Total synergies:
$\left[\mathrm{A}^{\mathrm{A}}-\mathrm{A}^{\mathrm{N}}\right]+\left[\mathrm{O}^{\mathrm{A}}-\mathrm{T}^{\mathrm{N}}\right]$
(1B) New information about $\mathrm{A}$ as standalone:
$\left[\mathrm{A}^{\mathrm{N}}-\mathrm{A}_{0}\right]$
(1C) New information revealed about target:
$\left[\mathrm{T}^{\mathrm{N}}-\mathrm{T}_{0}\right]$

Overpayment by the acquirer also can be measured as one part of the synergies:

(1D) Overpayment:

$\left[\mathrm{A}^{\mathrm{A}}-\mathrm{A}^{\mathrm{N}}\right]$

In addition, each unsuccessful firm, I, experiences a total value change equaling

(1E) New information revealed about acquirer, I:

$\left[\mathrm{I}^{\mathrm{N}}-\mathrm{I}_{0}\right]$

These terms can seldom be estimated separately. While the total value change is typically observable in completed acquisitions, there is usually not enough information to disentangle the value change into distinct components. For example, if the takeover is successful, then we do not observe $\mathrm{A}^{\mathrm{N}}$, the value of firm $\mathrm{A}$ as a stand-alone. Without $\mathrm{A}^{\mathrm{N}}$, we cannot calculate exact overpayments, nor can we calculate the value change due to new information revealed. The only information revelation we witness is that which concerns the unsuccessful bidders.

In the section 2.2, we use the link between present stock prices and expected future cash flows to set up a framework for inferring distinct sources of value change. Then, in section 3 , we discuss various takeover scenarios and describe when this framework yields inferences of overpayments, synergies, and information revelation. 


\section{B. Identifying the Sources of Value Change}

Because stock prices are (discounted) expected values of future cash flows, we can establish a system of equations that link market values at time 2 to the observed and unobserved market values at time 3. This link is the key to identifying situations in which the various components of Equation (1) can be uncovered. Arranging the market values and success probabilities of the firms involved in the takeover contest according to the set of potential outcomes, we can write stock prices as follows:

(2) $\quad \mathrm{A}_{2}=\mathrm{E}_{2}\left(\mathrm{~A}^{\mathrm{A}}{ }_{3} \theta^{\mathrm{A}}{ }_{2}+\mathrm{A}^{\mathrm{B}}{ }_{3} \theta^{\mathrm{B}}{ }_{2}+\mathrm{A}^{\mathrm{C}}{ }_{3} \theta^{\mathrm{C}}{ }_{2}+\ldots+\mathrm{A}^{\mathrm{N}}{ }_{3} \theta^{\mathrm{N}}{ }_{2} \mid \Omega_{2}\right)$

(3) $\quad \mathrm{B}_{2}=\mathrm{E}_{2}\left(\mathrm{~B}_{3}^{\mathrm{A}} \theta^{\mathrm{A}}{ }_{2}+\mathrm{B}_{3}^{\mathrm{B}} \theta^{\mathrm{B}}{ }_{2}+\mathrm{B}^{\mathrm{C}}{ }_{3} \theta^{\mathrm{C}}{ }_{2}+\ldots+\mathrm{B}^{\mathrm{N}}{ }_{3} \theta^{\mathrm{N}}{ }_{2} \mid \Omega_{2}\right)$

(4) $\mathrm{T}_{2}=\mathrm{E}_{2}\left(\mathrm{O}_{3}^{\mathrm{A}}{ }_{3} \theta_{2}^{\mathrm{A}}+\mathrm{O}_{3}^{\mathrm{B}} \theta^{\mathrm{B}}{ }_{2}+\mathrm{O}^{\mathrm{C}}{ }_{3} \theta^{\mathrm{C}}{ }_{2}+\ldots+\mathrm{T}^{\mathrm{N}}{ }_{3} \theta^{\mathrm{N}}{ }_{2} \mid \Omega_{2}\right)$

where $E_{2}$ is the expectation at time 2 of time 3 variables; $\theta_{2}^{I}$ is firm i's success probability at time $2 ; \theta^{\mathrm{N}}{ }_{2}$ is the probability that the target remains a stand-alone firm as of time 2 ; and $\Omega_{2}$ denotes the market's time 2 information about time 3 values. In matrix form, this system of equations is:

$$
\mathrm{P}_{2} \quad=\quad \mathrm{E}_{2}\left(\mathrm{P}_{3} \theta_{2} \mid \Omega_{2}\right),
$$

where $\mathrm{P}_{3}$ is the matrix obtained from time 3 firm values in equations (2)-(4) and $\mathrm{P}_{2}$ is the columnvector of current stock prices for each of the firms involved in the takeover contest. ${ }^{4}$ Equation (5) is the key to disentangling overpayments, synergy, and information revelations. It relates current stock prices to assessments of future market values and success probabilities for each firm involved in the takeover situation. At time 2, for $\mathrm{N}$ acquirers and one target, equation (5) is a system of $\mathrm{N}+1$ equations in $(\mathrm{N}+1)^{2}+$ $(\mathrm{N}+1)$ unknowns, since all of the $\theta^{\mathrm{I}}$, and the $\mathrm{I}^{\mathrm{J}}$ are unobservable ex ante..$^{5}$

At time 3, we either see $\mathrm{N}$ unsuccessful bidders and the stand-alone value of the target, $\mathrm{T}^{\mathrm{N}}$, or else we see one successful firm and N-1 unsuccessful ones, but not the stand-alone value of the target. Thus, it is never possible to separate stock price changes into three distinct sources. Our solution to this problem is to use time 3 observed values as proxies for the market's expectations at time 2. Then, in some situations, we can solve equation (1) for the unobservable data. For example, suppose that firm A

\footnotetext{
${ }^{4}$ We ignore expected returns because the time horizons in question are generally small.
} 
successfully acquires the target $\mathrm{T}$. This means that we observe $\mathrm{A}^{\mathrm{A}}, \mathrm{O}\left(\mathrm{A}^{\mathrm{A}}\right)$, and the stand-alone values of the losers- $\mathrm{B}^{\mathrm{N}}, \mathrm{C}^{\mathrm{N}}$, and the others. Equation (5) becomes:

$$
\begin{aligned}
\mathrm{A}_{2} & =\mathbf{A}^{\mathrm{A}} \theta^{\mathrm{A}}{ }_{2}+\mathrm{E}_{2}\left(\mathrm{~A}^{\mathrm{B}}{ }_{3} \theta^{\mathrm{B}}{ }_{2}+\mathrm{A}^{\mathrm{C}}{ }_{3} \theta^{\mathrm{C}}{ }_{2}+\ldots+\mathrm{A}^{\mathrm{N}}{ }_{2} \theta^{\mathrm{N}}{ }_{2} \mid \Omega_{2}\right) \\
\mathrm{B}_{2} & =\mathrm{E}_{2}\left(\mathrm{~B}_{3}{ }_{3} \theta^{\mathrm{A}}{ }_{2}+\mathrm{B}_{3}{ }_{3} \theta^{\mathrm{B}}{ }_{2}+\mathrm{B}^{\mathrm{C}}{ }_{3} \theta^{\mathrm{C}}{ }_{2}+\ldots \mid \Omega_{2}\right)+\mathbf{B}^{\mathrm{N}} \theta^{\mathrm{N}}{ }_{2} \\
\mathrm{~T}_{2} & =\mathbf{O}^{\mathrm{A}}\left(\mathbf{A}^{\mathrm{A}}\right) \theta^{\mathrm{A}}{ }_{2}+\mathrm{E}_{2}\left(\mathrm{O}^{\mathrm{B}}{ }_{3} \theta^{\mathrm{B}}{ }_{2}+\mathrm{O}^{\mathrm{C}}{ }_{3} \theta^{\mathrm{C}}{ }_{2}+\ldots+\mathrm{T}^{\mathrm{N}}{ }_{2} \theta^{\mathrm{N}}{ }_{2} \mid \Omega_{2}\right)
\end{aligned}
$$

where figures in bold denote observed values. Depending on the number of bidders involved in the acquisition contest, and the amount of information about future outcomes that is known in advance, it is sometimes possible to take the proxies that we have inserted into Equation (5) and use them to back out the remaining, unobserved values. In the next section we pinpoint the situations in which observed values can be used to disentangle the total value change in the acquisitions into its constituent parts. We also discuss whether it is reasonable to use time 3 values as proxies for the market's expectations of those values at time 2 .

\section{When Can Information Be Extracted?}

In this section, we analyze and classify takeover situations based on how much information can be extracted from stock prices during a takeover contest. In general, there are too few ex ante restrictions and ex post observables to be able to solve Equation (5) for synergies and overpayments. However, as Table 1 summarizes, there are two situations in which inferences are possible: (i) when a takeover battle between two bidders and one target occurs and the market knows in advance that one will win with certainty; and (ii) when a failed takeover attempt by a single bidder occurs.

The first step is to make assumptions that limit the number of distinct firm values one has to estimate. In terms of Equation (5), we assume that, for all distinct firms $\mathrm{I}$ and $\mathrm{J}, \mathrm{I}^{\mathrm{J}}=\mathrm{I}^{\mathrm{N}}$. In other words, if firm B is unsuccessful in the takeover, then the identity of the winning bidder has no impact on the value of firm B - losing the contest to one firm is no different from losing the contest to another firm.

\footnotetext{
${ }^{5}$ The number of unknowns is so large because the P matrix need not be symmetric. Later we simplify the analysis by assuming that it is symmetric.
} 
This assumption is potentially inappropriate in situations in which two firms in the same industry are bidding for a target that, if acquired, would give one firm a market advantage over the other. ${ }^{6}$ There are two reasons why we still make this assumption. Most importantly, it simplifies our analysis, but does not affect our results - the assumption is irrelevant for the two circumstances in which inferences are possible. In addition, the evidence in Eckbo ((1985) and (1992)) suggests that the assumption is reasonable. He studies the stock price reactions to rival firms when a merger is announced and finds that rival firms earn essentially zero abnormal returns. Although he does not focus explicitly on losing parties in a merger transaction, his evidence suggests that this assumption seems reasonable for our purposes, since it suggests that the market value of neighboring firms to a merger is unaffected by the merger outcome.

This assumption reduces the number of bidder stock prices in Equation (5) from $(n+1)^{2}$ to $2 n+2 .^{7}$ Ex ante, none of these are visible, but at time 3, n+1 stock prices are revealed, leaving $\mathrm{n}+1$ stock prices and $n+1$ probabilities to be calcula ted.

We divide the takeover situations into two categories based on market beliefs at time 2, (that is, at the point in time when the final bids have been made but the final outcome is not yet known). The categories are:

- Category I: Takeover situations in which the market knows at time 2 that one of the bidders will take over the target. That is, the winning probabilities sum to one, and this information is known at time 2 .

- Category II: Takeover situations in which the market believes at time 2 that there is a positive probability that the target will not accept any of the bids but will continue as an independent stand-alone company. That is, the sum of the winning probabilities is strictly less than one.

In Category I, the ex ante information about takeover probabilities works to eliminate one element of the $\theta$ vector in equation (5), because $\theta^{\mathrm{N}}=0$. Also, setting $\theta^{\mathrm{N}}=0$ zeros out $\mathrm{N}$ additional elements of the $\mathrm{P}_{3}$ matrix. Empirically, we can assign a takeover situation into category I when the target

\footnotetext{
${ }^{6}$ For example, see Esty (1998).

${ }^{7}$ The $2 n+2$ unknowns comes from the fact that there are two unknowns per firm, and there are are $n+1$ firms.
} 
has put itself "on play" or organizes an auction among the potential acquirers. A more typical takeover situation would be assigned to category II.

Ex post (at time 3), we can further divide category II takeover situations into two subcategories based on the final outcome:

- Category II-A: Takeover situations in category II in which the final outcome is that the target is taken over by one of the bidders.

- Category II-B: Takeover situations in category II in which the final outcome is that the target stays independent.

Ex post information further shapes the $\mathrm{P}_{3}$ matrix from equation (5). Depending on the number of firms involved in the takeover, we can sometimes obtain solutions of all the variables in question, thereby enabling us to determine stand-alone values, synergies, and overpayments. In the following three subsections, we analyze the categories separately to determine the takeover situations where we can disentangle either the total value change in the acquisition or the total value change in the acquirer's market valuation.

\section{A. Information Extraction in Category $I$}

In this category, we know in advance (at time 2) that one of the bidders will take over the target at time 3. We can further divide the takeovers in this category by the number of bidders.

\section{A.1 $\quad \mathrm{N}=1$}

This is a trivial case where we have a sole bidder that will acquire the target with complete certainty. In this case we cannot isolate any of the total value changes as $T_{2}=O^{A}\left(A^{A}\right)$ and $A_{2}=$ $\mathrm{A}^{\mathrm{A}}{ }^{8}$. Thus, we cannot solve for information effects, overpayment, or synergies since we cannot observe (or solve for) $\mathrm{A}^{\mathrm{N}}$ and $\mathrm{T}^{\mathrm{N}}$.

\section{A.2 $\mathrm{N}=2$}

In this case, the stock prices at time 2 reflect the market estimates of $\theta^{\mathrm{A}}, \mathrm{A}^{\mathrm{A}}$, and $\mathrm{B}^{\mathrm{B}}$ (at time 3 ) in the following way:

\footnotetext{
${ }^{8}$ This is the original case studied by Grossman and Hart (1980).
} 


$$
\begin{aligned}
\mathrm{A}_{2} & =\theta^{\mathrm{A}} \mathrm{A}^{\mathrm{A}}+\left(1-\theta^{\mathrm{A}}\right) \mathrm{A}^{\mathrm{N}} \\
\mathrm{B}_{2} & =\theta^{\mathrm{A}} \mathrm{B}^{\mathrm{N}}+\left(1-\theta^{\mathrm{A}}\right) \mathrm{B}^{\mathrm{B}} \\
\mathrm{T}_{2} & =\theta^{\mathrm{A}} \mathrm{O}^{\mathrm{A}}\left(\mathrm{A}^{\mathrm{A}}\right)+\left(1-\theta^{\mathrm{A}}\right) \mathrm{O}^{\mathrm{B}}\left(\mathrm{B}^{\mathrm{B}}\right)
\end{aligned}
$$

At time 2, we observe $A_{2}, B_{2}, T_{2}$ and functional forms of $\mathrm{O}^{A}(A)$, and $\mathrm{O}^{\mathrm{B}}(\mathrm{B})$. At time 3 , we

additionally observe $\mathrm{A}^{\mathrm{A}}, \mathrm{B}^{\mathrm{B}}$, and $\mathrm{O}^{\mathrm{A}}\left(\mathrm{A}^{\mathrm{A}}\right)$. We thus have three equations to solve for three unknowns: $\mathrm{A}^{\mathrm{N}}$, $\mathrm{B}^{\mathrm{B}}$, and $\theta^{\mathrm{A}}$ ?

In this takeover situation we can estimate information effects for both acquirers (as we know $\mathrm{A}_{0}$, $\mathrm{B}_{0}, \mathrm{~A}^{\mathrm{N}}$, and $\mathrm{B}^{\mathrm{N}}$ ), overpayment by $\mathrm{A}$ (as we know $\mathrm{A}^{\mathrm{A}}$ and $\mathrm{A}^{\mathrm{N}}$ ) and the overpayment which $\mathrm{B}$ offered to make (as we know $\mathrm{B}^{\mathrm{B}}$ and $\mathrm{B}^{\mathrm{N}}$ ). We fall short of estimating the synergies as we cannot solve for $\mathrm{T}^{\mathrm{N}}$ in this case. However, since $\mathrm{T}^{\mathrm{N}}$ is unaffected by which bidder takes over the target, we can determine whether the synergies would have been higher with A or B. The following numerical example illustrates this kind of takeover situation.

Example 1: Before the takeover battle starts (at time 0) we observe $A_{0}=\$ 72, B_{0}=\$ 60$, and $T_{0}=\$ 20$. In the end of the takeover battle, the final bids from $A$ and $B$ are:

$$
\begin{array}{rll}
O^{A}\left(A^{A}\right) & = & (1 / 2) A^{A} \\
O^{B}\left(B^{B}\right) & = & 10+(1 / 3) B^{B}
\end{array}
$$

At time 2, the market knows that the target's board will pick one of the offers. The market prices at this time point are $A_{2}=\$ 63, B_{2}=\$ 60$, and $T_{2}=\$ 28$. Because Firm A's stock has dropped so dramatically, the board decides to accept $B$ 's offer and we observe afterwards that

$$
\begin{array}{ll}
A^{N}= & \$ 70.8 \\
B^{B}= & \$ 59.4 \\
O^{B}\left(B^{B}\right)= & \$ 29.8 .
\end{array}
$$

Thus we get the following three equations:

$$
\begin{array}{ll}
\$ 63= & \theta^{A} A^{A}+\left(1-\theta^{A}\right) \$ 70.8 \\
\$ 60= & \theta^{A} B^{N}+\left(1-\theta^{A}\right) \$ 59.4 \\
\$ 28= & \theta^{A}\left[1 / 2\left(A^{A}\right)\right]+\left(1-\theta^{A}\right)[\$ 10+1 / 3 \$ 59.4]
\end{array}
$$

From these three equations we obtain:

$$
\begin{array}{ll}
A^{A}= & \$ 50 \\
B^{N}= & \$ 61 \\
O^{A}\left(A^{A}\right)= & \$ 25 \\
\theta^{A}= & 0.375
\end{array}
$$

\footnotetext{
${ }^{9}$ As mentioned above, the assumption that $\mathrm{A}^{\mathrm{J}}=\mathrm{A}^{\mathrm{N}}$ is not relevant here.
} 
Using these values, we determine that:

$\begin{array}{lcc}\text { Information about } A & A^{N}-A_{0}= & -\$ 1.2 \\ \text { Information about } B & B^{N}-B_{0}= & \$ 1.0 \\ \text { Overpayment by } A & A^{N}-A^{A}= & \$ 20.8 \\ \text { Offered Overpayment by } B & B^{N}-B^{B}= & \$ 1.6\end{array}$

Additionally we can calculate synergies fro the two offers using $\left[A^{A}-A^{N}\right]+\left[O^{A}-T^{N}\right]$. The market estimates:

$$
\begin{array}{llll}
\text { Synergies for A: } & \$ 50-\$ 70.8+\$ 25-T^{N} & = & \$ 4.2-T^{N} \\
\text { Synergies for } B: & \$ 59.4-\$ 61+\$ 29.8-T^{N} & = & \$ 28.2-T^{N}
\end{array}
$$

We can say, therefore, that the synergies with B exceed those with A by $\$ 24$. Because we do not observe $T^{N}$, we cannot solve for information revealed about $T$ or for the absolute amount of synergies.

\section{A.3 $\quad \mathbf{N}>2$}

In a general case with $\mathrm{N}$ acquirers, we must try to solve for $\mathrm{N}-1$ probabilities and $\mathrm{N}$ stock prices with $\mathrm{N}+1$ equations. This system of equations cannot be solved if $\mathrm{N}>2$, and thus the only takeover situation in category I which can be solved for overpayment and 'comparative' synergies - which bidder adds more value - is the case with two bidders.

\section{B. Information Extraction in Category II-A}

In this category, there is positive probability ex ante (at time 2) that the target stays independent, but, in fact, at time 3 , one of the bidders actually takes over the target. The fact that $\theta^{\mathrm{N}}$ does not equal 0 at time 2 means that we do not lose any of the $\mathrm{I}^{\mathrm{N}}$ elements of the $\mathrm{P}_{3}$ matrix in Equation (5). Furthermore, each of the probabilities is unknown. This leaves $\mathrm{N}+1$ stock prices and $\mathrm{N}+1$ probabilities.

As a result, we must recover $\mathrm{N}+1$ stock prices and $\mathrm{N}+1$ probabilities from only $\mathrm{N}+1$ equations. No unique solution exists, and thus, there does not exist a single takeover situation in category IIA for which we can solve for overpayments or synergies. 


\section{Information Extraction in Category II-B}

In this category, there exists a positive probability at time 2 that the target stays independent; at time 3, we learn that the takeover attempt fails. It is useful again to divide takeover situations in this category based on the number of bidders.

\section{C.1 $\quad \mathrm{N}=1$}

At time 2, with only one bidder we have two equations. Because only one bidder is involved, a single probability is sufficient to describe the set of outcomes that can arise at time 3 . Thus, stock prices satisfy:

$$
\begin{aligned}
\mathrm{A}_{2} & =\theta^{\mathrm{A}} \mathrm{A}^{\mathrm{A}}+\left(1-\theta^{\mathrm{A}}\right) \mathrm{A}^{\mathrm{N}} \\
\mathrm{T}_{2} & =\theta^{\mathrm{A}} \mathrm{O}^{\mathrm{A}}\left(\mathrm{A}^{\mathrm{A}}\right)+\left(1-\theta^{\mathrm{A}}\right) \mathrm{T}^{\mathrm{N}}
\end{aligned}
$$

At time 2, we observe $\mathrm{A}_{2}, \mathrm{~T}_{2}$, and the functional form of $\mathrm{O}^{\mathrm{A}}$. At time 3 , we additionally observe $\mathrm{A}^{\mathrm{N}}$ and $\mathrm{T}^{\mathrm{N}}$. Thus, we have two equations and two unknowns: $\mathrm{A}^{\mathrm{A}}$ and $\theta^{\mathrm{A}}$. Assuming that $\mathrm{A}^{\mathrm{A}}$ ? $\mathrm{A}^{\mathrm{N}}$, we can use the first equation to obtain $\theta^{\mathrm{A}}$. With this, we can use the second equation to solve for $\mathrm{A}^{\mathrm{A}}$. It is worth stressing that this analysis requires the assumption that the expectation of $\mathrm{A}^{\mathrm{N}}$ at time 2 is equal to $\mathrm{A}^{\mathrm{N}}$ at time 3. We discuss the validity of this assumption in section 2.D.

In this takeover situation we can estimate information effects for both the bidder and the target, the proposed overpayment by A, and the synergies that would have happened had the merger occurred. The following numerical example illustrates this type of takeover situation.

Example 2: Before the takeover battle starts (at time 0), we observe $A_{0}=50$, and $T_{0}=\$ 19$. Firm A makes a final bid: $O^{A}\left(A^{A}\right)=\$ 10+1 / 3\left(A^{A}\right)$. At time 2, the market knows that either the bid will be accepted by the board or the bid will be rejected and the takeover contest will be over. The market prices are $A_{2}=\$ 48$ and $T_{2}=\$ 24$. The bid fails (because of a takeover defense or anti-trust challenge) and the contest is over. The new prices in the market are $A^{N}=\$ 49$ and $T^{N}=\$ 21$.

We solve for $A^{A}=\$ 47.4$ and thus $O^{A}\left(A^{A}\right)=\$ 25.8$. The following information is revealed:
Information about $A$
$A^{N}-A_{0}$
$=-\$ 1$ 
Information about $T$

Offered Overpayment by A

Proposed Synergies

$$
\begin{array}{ll}
T^{N}-T_{0} & =\$ 2 \\
A^{N}-A^{A} & =\$ 1.6 \\
{\left[A^{A}-A^{N}\right]+\left[O^{A}\left(A^{A}\right)-T^{N}\right]} & =\$ 3.2
\end{array}
$$

\section{C.2 $\quad \mathrm{N}>1$}

The case of more than one firm in category IIB is similar to that of category IIA with more than two firms. In general, with $\mathrm{N}$ acquirers we must find $\mathrm{N}$ stock prices and $\mathrm{N}$ probabilitie $\mathrm{s}$ with only $\mathrm{N}+1$ equations. This system is under-identified, and thus the only takeover situation in category IIB that can be solved for synergies and overpayments is the case of a single bidder.

\section{Information assumptions}

In this section, we discuss the extent to which it is likely that the information assumptions in our analysis are met in practice. The analysis has (at least) two important and nontrivial information requirements. First, the analysis assumes that time 3 is a discrete time or event. In other words, there is a clear date at which (1) the market knows the takeover will be consummated for Category I acquisitions; and (2) the market knows the takeover will not occur for Category II-B acquisitions. Second, the analysis assumes that the market does not gain new information about the underlying values of the bidders, targets, and synergies from time 2 to time 3 . This means that we assume that the actual time 3 realized values of the bidders and targets are the values that the market expected at time 2 .

The first assumption that time 3 is a discrete date may not be appropriate for many Category II-B acquisitions. Even if a target announces that an acquisition is out of the question or if a bidder announces that it is no longer pursuing the target, the market may still put a non-zero probability on the likelihood that the target will be taken over. Consistent with this, Bradley, Desai and Kim (1983) show that targets of unsuccessful bids decline in value for some period after the bid is withdrawn. The first assumption is more appropriate for Category I acquisitions, particularly in those instances where the target has put itself up for sale. 
The second assumption also may be violated for both Category I and Category II-B acquisitions. For example, the withdrawal or defeat of a takeover bid may convey information about the bidder and the target, changing the values of $\mathrm{A}^{\mathrm{N}}$ and $\mathrm{T}^{\mathrm{N}}$. As a result, the expectation of $\mathrm{A}^{\mathrm{N}}$ (or $\mathrm{T}^{\mathrm{N}}$ ) at time 2 may not equal the realization of $\mathrm{A}^{\mathrm{N}}\left(\right.$ or $\left.\mathrm{T}^{\mathrm{N}}\right)$ at time.

Our analysis in the previous sections showed that there are only two types of takeover situations in which it is theoretically possible to extract information on synergies and overpayments from stock prices for a particular takeover contest. The discussion in this section suggests that the problem is more difficult than this. Even in situations in which it is theoretically possible, it may not be practically possible to extract the information because the necessary assumptions do not hold.

In the next two sections, we describe the Paramount - Viacom - QVC takeover contest. We argue that this contest corresponds as closely as possible to our theoretical category I contest with 2 bidders. This contest is particularly appropriate because it ended with a court-mandated auction that involved two bidders - Viacom and QVC. The auction process had a well-defined end point at which final bids were due, corresponding to time 2. At time 2, it also was virtually certain that Paramount would be sold to one of the two bidders. Consistent with our first assumption, the process also had a well-defined end point at which the winner would be declared, corresponding to time 3 .

It is still uncertain whether the second assumption is satisfied. Consistent with the second assumption, it is plausible that the market did not gain any new information about the underlying values of the bidders, targets, and synergies from time 2 to time 3 . The contest had been going on for almost five months at the time final bids were due (time 2). Thus, while there are aspects of the contest that are not ideal, particularly the complexity of the Viacom offer, it is close to ideal in corresponding closely to a Category I contest with 2 bidders.

If these assumptions hold, there is still one potential concern. If no information changed from time 2 to time 3, and the acquisition was certain to occur, why wasn't the winner already determined at time 2? In other words, why didn't arbitrage activity drive stock prices at time 2 to equal the prices at time 3? There are at least three possible responses to this. 
One explanation relies on differences in information among shareholders. If some shareholders are more informed than others, the less informed shareholders will need to use share prices to infer the information held by the more informed. Bebchuk and Hart (2001) analyze precisely this situation in the context of a control contest. Frictions or fixed costs in becoming informed or in inferring the information could result in share prices not adjusting instantaneously. (See Mitchell, Pulvino and Stafford (2001)).

A second explanation is that both bids were valued at roughly the same value making it very difficult to determine the winner at time 2 .

A third explanation is that shareholders believed it was possible that one of the bidders would withdraw leaving the other bidder the winner, but that it was almost a zero probability event that both bidders would withdraw at the same time.

\section{The Paramount - Viacom - QVC Takeover Contest}

We apply the analytical apparatus developed above to the Paramount acquisition contest that began in summer of 1993 and culminated in a takeover auction in February, $1994 .{ }^{10}$ This contest corresponds closely to category I of section 2 for which it is possible to estimate overpayments and relative synergies.

Paramount, Viacom, and QVC are familiar names in the motion picture and cable television businesses. At the time of the contest, Paramount produced and distributed entertainment products, including motion picture films, home movies, and television programming. The "Star Trek" television and movie series was one of Paramount's most valuable properties. Martin Davis was Paramount's CEO at the time of the contest. Viacom operated a number of entertainment and communications businesses including several cable television networks: MTV, VH-1, Nickelodeon, The Movie Channel, Comedy Central, Lifetime, FLIX, and the All News Channel. Viacom was majority owned and controlled by its chairman and CEO, Sumner Redstone. QVC, the smallest of the three companies at the time of the

\footnotetext{
${ }^{10}$ This section is based on Kaplan (1994a), Kaplan (1994b), Paramount Communications 13E3 (May 25, 1994), and the opinion of the Delaware Court of Chancery (1993).
} 
contest, operated the nation's largest home-shopping television network. QVC's CEO was Barry Diller who had formerly been a senior executive at Paramount and at Fox where he launched the Fox television network. Diller had a strong reputation in the television and movie industries.

Viacom made a friendly takeover offer for Paramount on September 12, 1993. Paramount's board accepted the offer and agreed to a substantial lock-up option and termination fee. Paramount's board also agreed to lift Paramount's poison pill for the transaction. QVC followed one week after Viacom's offer with a hostile tender offer. The tender offer did not have the support of Paramount's board and, therefore, was conditional on the removal of Paramount's poison pill. A lengthy battle ensued during which both firms increased their bids for Paramount.

Because Paramount's board refused to consider QVC's offer (and remove the poison pill), QVC sued Paramount and Viacom countersued to protect its transaction. Ultimately, the Delaware Chancery Court ruled in favor of QVC. The court required Paramount's board to consider all offers. Paramount's board responded by conducting an auction for control of the company. In the end, Viacom won the auction.

Our analysis shows that Viacom dramatically overpayed for Paramount. In fact, based on the downward spiral of QVC's and Viacom's stock prices, the market consensus was that both firms were overpaying. Any would-be synergies between Viacom or QVC and Paramount were dwarfed by this downward revision in Viacom and QVC. In spite of the fact that both firms were overbidding, Viacom so overpaid for Paramount - by roughly $\$ 1.5$ billion - that its offer prevailed. In the rest of this section we describe these events in greater detail and study the stock price movements surrounding the merger announcements and subsequent developments.

\section{A. Viacom and Paramount Agree to a Combination}


On September 12, 1993, the board of directors of Paramount Communications approved the following transaction. For each Paramount share, Viacom would pay (i) $\$ 9.10$ in cash, (ii) 0.1 shares of Viacom Class A voting common stock, and (iii) 0.9 shares of Viacom Class B non-voting common stock. This consideration was valued at $\$ 69.14$ per share based on closing stock prices on September 10 . According to the terms of the agreement, Paramount's CEO, Martin Davis, would manage the combined entity as CEO, but Viacom's CEO, Sumner Redstone, would maintain control of roughly $70 \%$ of the voting shares.

At the beginning of the week before the announcement, (on September 7), Paramount stock traded at $\$ 55.875$ per share. From that point, Paramount stock began to rise, reaching $\$ 61.125$ on September 10 (the Friday before the announcement) and $\$ 64.50$ on September 13 (the Monday after the announcement). The market reacted unfavorably to Viacom. From September 7 to 13, Viacom Class A stock fell from $\$ 66.125$ per share to $\$ 64.125$. Viacom Class B stock, to which no voting rights were attached, declined from $\$ 59.25$ to $\$ 56.75$ over the same period. On Tuesday, September 14 , the Class A and B shares declined again, to $\$ 61.50$ and $\$ 55.375$ per share, respectively. Paramount declined to \$63.125. The S\&P 500 was essentially unchanged over the same week.

The share price movements imply an increase in Paramount's value of roughly $\$ 1$ billion (120 million shares outstanding) and a decline in Viacom's value of $\$ 0.5$ billion (also 120 million A and B shares outstanding). The drop in Viacom's market value implies that the market had an overall negative evaluation of (1) the price Viacom was paying and (2) the new information about Viacom from the bid. The overall gain from the transaction announcement of $\$ 0.5$ billion net gain reflects the sum of synergies, overpayments, and new information about stand-alone values.

As part of the offer, Paramount granted Viacom an option to purchase 23.7 million Paramount shares at $\$ 69.14$ per share and agreed to pay a $\$ 100$ million termination fee if any of three contingencies arose: (a) Paramount terminated the agreement because of a competing bid; (b) Paramount's shareholders did not approve the transaction; or (c) Paramount's Board recommended a competing bid. Furthermore, if 
the option were exercised, its strike price could be paid with a combination of cash (for the par value of the stock, or $\$ 1$ per share) and senior subordinated notes (for the remainder). ${ }^{11}$

\section{B. QVC Enters}

On September 20, QVC launched a hostile bid for Paramount. In a letter to Paramount, QVC proposed a business combination of Paramount and QVC under which each outstanding share of Paramount would receive 0.893 of a share of QVC and \$30 in cash. Before the offer, QVC closed at $\$ 59.50$ per share implying a value of $\$ 83.13$ for the offer. QVC's bid had the support of TeleCommunications Inc. (TCI), the country's largest cable television company. Davis and Paramount responded that Viacom was a better fit, but that Paramount would potentially consider a QVC offer.

The market's reaction to this announcement was negative; QVC's stock price dropped $\$ 3.50$ from $\$ 59.50$ on Friday, September 17, to $\$ 56$ on Monday, September 20. Going back to September 13 (or September 7), the stock price drop was more severe: QVC traded at \$62.75 (\$63) one week earlier (and one week before the announcement of the Viacom-Paramount agreement). At $\$ 56$ per share, the offer from QVC was valued at $\$ 80$ per share $(\$ 30$ cash $+.893(\$ 56))$. This substantially exceeded the value of the Viacom offer ( $\$ 63$ at Viacom share prices on September 20).

\section{The Takeover Battle}

On September 23, Viacom filed an anti-trust suit against QVC and TCI. Four days later, Davis told his board that acceptance of the QVC offer would trigger Viacom's termination fee and lock-up option. Nevertheless, the board decided to consider the QVC offer, but only if QVC could provide evidence of financing. ${ }^{12}$

\footnotetext{
${ }^{11}$ A $\$ 100$ million termination fee amounts to $\$ 0.83$ per share. The option had the effect of requiring a rival bidder to pay Viacom $\$ 0.20$ per share for every $\$ 1$ it paid above $\$ 69.14$ per share.

12 This chronology is based on accounts in the Paramount Communications Proxy Statement, dated June 6, 1994, and the March 1994 Corporate Control Alert (published by American Lawyer Media, LLP.)
} 
By October 21, Paramount still had failed to enter into negotiations with QVC. Partly in response to Paramount's inaction, QVC, along with Paramount shareholders, filed a class action suit in the Delaware Court of Chancery on October 21, seeking to prevent the proposed merger between Paramount and Viacom and, in particular, to invalidate Viacom's option to purchase 23.7 million Paramount shares. The plea also asked the court to prohibit Paramount from using its stockholder rights plan (poison pill) to oppose QVC's bid.

On the same day, QVC publicly announced that it would begin a tender offer for $51 \%$ of Paramount's shares at $\$ 80$ per share and, if successful, would propose a second-step merger in which the remaining shares would be converted into QVC common stock. This offer was contingent on the invalidation of both the poison pill and the lock-up option. Viacom responded by increasing its offer to the same $\$ 80$ per share of Paramount. Viacom also began a tender offer for $51 \%$ of the Paramount shares outstanding at a price of $\$ 80$ in cash per share following which, in a second-step merger, holders of the remaining $49 \%$ of Paramount shares would receive a portfolio of Viacom securities, including common stock, preferred stock, and warrants.

Table 2 catalogs the actions taken by Viacom and QVC as each tried to outdo one another's takeover proposals. This process continued throughout the autumn of 1993, until the Delaware Chancery Court ruled in favor of QVC on November 24. The court's decision refined the standards for injunctive relief that were relevant in merger transactions. Before this ruling, several potentially conflicting precedents offered alternative views as to whether Paramount faced enhanced fiduciary duty in this situation. The court ultimately ruled that the events surrounding the Viacom merger triggered a heightened standard of duty, one that Paramount had not met. As a result, the agreed-upon acquisition by Viacom was blocked. The court ruling also barred Paramount from using its poison pill defense against QVC and struck down Paramount's stock option lockup. The ruling did uphold the $\$ 100$ million termination fee payable to Viacom if the merger were to fail.

The courts' ruling increased the probability that QVC would be the winning bidder. QVC's stock price fell from $\$ 48.875$ to $\$ 47.750$. At the same time, Viacom's A (B) shares rose from $\$ 47.750$ to 
$\$ 50.625$ ( $\$ 41.75$ to $\$ 44.50$ ). Paramount's stock price also increased from $\$ 76.25$ to $\$ 80.125$. These reactions suggest that the market expected both QVC and Viacom to overpay if they ultimately prevailed.

On December 9, 1993, the Delaware Supreme Court upheld the Chancery Court ruling, effectively mandating that Paramount's board seriously consider all offers. As a result, on December 14, Paramount's board dropped the merger agreement with Viacom and agreed to hold an auction for control of Paramount. ${ }^{13}$

Under the terms of the auction, Paramount asked each bidder to submit its best offer by 4:00 pm, December 20. Both bidders would begin simultaneous tender offers. Although Paramount would endorse one of the two bids, the shareholders' tender decisions ultimately would decide the winner. The bidders would be allowed to revise their offers any time within ten business days. The auction would end when one bidder obtained tenders of more than 51\% of Paramount's shares. Paramount also required that the winning offer remain open for 10 days after being declared the winner in the initial tender round, so that shares tendered to the losing bidder could be withdrawn and tendered to the winner. ${ }^{14}$ Paramount set February 1 as the absolute final deadline for bids and counterbids -- after this date, the bidders would be allowed no further changes to their bids.

On December 20, Viacom and QVC each submitted acquisition proposals to the Paramount Board. These are described in Table 2. A day later, Paramount's Board received the written opinion of Lazard Freres, stating that QVC's current plan was fair to Paramount stockholders and was superior to Viacom's current offer. Based on this opinion, Paramount signed a merger agreement with QVC. Nevertheless, the bidding continued.

On January 7, 1994, Viacom announced a \$9.4 billion merger with Blockbuster Entertainment, and consequently, a new bid for Paramount. The market's reaction to these events clearly reflected the consensus that both firms were overpaying for Paramount. The probability of Viacom winning control

\footnotetext{
${ }^{13}$ The Chancery Court opinion did not force Paramount to undertake an auction. It merely held Paramount's board to a higher standard of scrutiny when considering a merger offer. They would not be in breach of their duties as long as they made a merger decision based on evidence that allowed them to judge all offers on equal footing.

${ }^{14}$ Wall Street Journal, December 15, 1993.
} 
increased; Viacom A shares fell from $\$ 47$ per share to $\$ 461 / 8$ while B shares fell from $\$ 41$ to $\$ 38.25$. Meanwhile the probability of QVC winning declined; QVC shares increased by $\$ 11 / 8$ to $\$ 40.625$. At the same time, Paramount stock price rose $\$ .75$ per share.

\section{The Final Bids}

On January 12, Lazard Freres issued an opinion that QVC's offer was both fair to Paramount stockholders and superior to Viacom's offer. On January 18, Viacom again increased the cash portion of its bid, and amended the terms of the second-step merger to provide for the exchange of (i) 0.93065 shares of Viacom Class B Common Stock, (ii) 0.30408 shares of Viacom Merger Preferred Stock, (iii) 0.93065 Contingent Valuation Rights (CVRs) ${ }^{15}$, and (iv) 0.5 Viacom Three-Year Warrants for each Paramount share remaining after consummation of the offer. On January 21, Lazard Freres opined that both the QVC and Viacom offers were fair, but that the Viacom offer was marginally superior to the QVC offer.

Finally, on February 1, both Viacom and QVC submitted their final proposals for Paramount. Table 3 outlines these proposals. Viacom offered $\$ 107$ per share in cash for $50.1 \%$ of Paramount's shares, and increased the offer for each remaining Paramount share in a second-step merger to (i) 0.93065 shares of Viacom Class B Common Stock, (ii) 0.93065 CVRs, (iii) 0.5 Viacom Three-Year Warrants, (iv) 0.3 Viacom Five-Year Warrants and (v) \$17.50 in principal amount of Viacom Merger Debentures with an $8 \%$ coupon and 12 year maturity if the Blockbuster-Viacom merger was approved. If the merger was not approved, the debentures would be replaced with $\$ 17.50$ face value of Viacom preferred stock with a $5 \%$ dividend yield.

Meanwhile, QVC increased its offer to $\$ 104$ per share in cash for $50.1 \%$ of Paramount's shares and (i) 1.2361 shares of QVC Common Stock, (ii) 0.2386 shares of New QVC Merger Preferred Stock, and (iii) 0.32 ten-year warrants for each remaining Paramount share in a second-step merger. ${ }^{16}$

\footnotetext{
15 The Contingent Valuation Rights (CVRs) are described in greater detail in Appendix A.

${ }^{16}$ In each case, individual securities within the package could be sold separately.
} 
On February 15, Viacom was declared the winner when over 50\% of Paramount's shares were tendered to Viacom's offer. By that time, Viacom B (A) shares had declined to $\$ 28.00$ (\$34.125) per share; QVC had risen to $\$ 50.25$ per share; and Paramount traded at $\$ 77.00$ per share.

\section{Determining Overpayment and Relative Synergy in the Paramount Contest ${ }^{17}$}

The structure of Paramount's auction corresponds closely to our Category I takeover with two bidders. The dates from February 2 to February 14 represent potential time 2's in our analysis. February 1 was the last date that the bidders could revise their bids. The deadline was after the market close.

Therefore, beginning on February 2: final bids were set; investors were arguably virtually certain that one of the two bidders would acquire Paramount; but investors were uncertain which bidder would prevail. All of the other dates between February 2 and February 15 also are consistent with time 2 in our analysis. In this section, we attempt to estimate the degree to which Viacom overpaid, and determine whether Viacom or QVC had greater synergies with Paramount.

Using the methodology of section 3, the stock prices for the target and the two bidders as of February 2 (or the dates from February 2 to February 14) yield a system of three equations in five unknowns. The five unknowns are: (1) the probability of Viacom's success, $\theta^{\mathrm{A}} ;$ (2) the value of Viacom if it wins, $A^{A}$; (3) if it loses, $A^{N}$; (4) the value of QVC if it wins, $B^{\mathrm{B}}$; and (5) the value of QVC if it loses, $\mathrm{B}^{\mathrm{N}}$. The value of Viacom if it wins, and QVC if it loses are revealed by the outcome of the auction (as $\$ 28.00$ and $\$ 50.25$ ). We use these actual market prices as proxies of the market's expectation before the close of the auction to reduce the system to three equations and three unknowns: $\theta^{A}, A^{N}, B^{B}$.

We begin by reproducing the equations from section 3.1.2:

$$
\begin{aligned}
\mathrm{A}_{2} & =\theta^{\mathrm{A}} \mathrm{A}^{\mathrm{A}}+\left(1-\theta^{\mathrm{A}}\right) \mathrm{A}^{\mathrm{N}} \\
\mathrm{B}_{2} & =\theta^{\mathrm{A}} \mathrm{B}^{\mathrm{N}}+\left(1-\theta^{\mathrm{A}}\right) \mathrm{B}^{\mathrm{B}} \\
\mathrm{T}_{2} & =\theta^{\mathrm{A}} \mathrm{O}^{\mathrm{A}}\left(\mathrm{A}^{\mathrm{A}}\right)+\left(1-\theta^{\mathrm{A}}\right) \mathrm{O}^{\mathrm{B}}\left(\mathrm{B}^{\mathrm{B}}\right)
\end{aligned}
$$

\footnotetext{
${ }^{17}$ In the analyses in this section, we do not include adjustments for market movements because the S\&P 500 was relatively stable over the first two weeks of February 1994 as well as from September 7, 1993 to February 15, 1994. Including such adjustments would not affect any of our results.
} 


\section{A. Valuing the Viacom and QVC offers}

The analysis is complicated by the fact that the offers Viacom and QVC gave to Paramount are non-linear functions of the Viacom and QVC stock prices conditional on their winning the contest. We necessarily begin, therefore, by valuing those offers, $\mathrm{O}^{\mathrm{A}}\left(\mathrm{A}^{\mathrm{A}}\right)$ and $\mathrm{O}^{\mathrm{B}}\left(\mathrm{B}^{\mathrm{B}}\right)$.

Viacom's final offer contained a mix of three-year warrants, five-year warrants, debt or preferred, cash, equity, and CVRs. Based on the closing price of Viacom's B shares on February 3, Lazard Freres' valued the offer at $\$ 83.31$ - \$53.61 in cash, $\$ 8.41$ in debt, $\$ 15.79$ in common stock, and $\$ 5.49$ in warrant and CVR value. ${ }^{18}$ This compares to the initial offer in September of $\$ 69.14$ of which only $\$ 9.10$ was in cash. The analyses are presented in table 4.

QVC's consisted of a package of cash, preferred stock, QVC common stock and warrants. Based on the closing price of QVC's shares on February 3, Lazard Freres' valued the offer at $\$ 86.72-\$ 52.10$ in cash, $\$ 3.76$ in preferred stock, $\$ 28.30$ in common stock, and $\$ 2.55$ in warrant value. ${ }^{19}$ This compares to the initial offer in September of $\$ 80.01$ of which $\$ 30.00$ was in cash. The analyses also are presented in table 4.

The Lazard analyses are inaccurate in two ways. First, they rely on the Viacom and QVC stock prices that prevailed on February 3 (and in September for the initial offer), rather than their respective stock prices conditional on winning. As Lazard Freres' noted, the use of the prevailing stock prices was inappropriate, because those prices partially reflected the possibility that either bidder would not win the contest. According to Lazard Freres, "the more relevant comparison is of the value of the winner's bid versus the value at which the loser's bid would theoretically have traded had it prevailed ... More importantly, with the bidding process that has been established, Paramount's shareholders (who are

\footnotetext{
${ }^{18}$ The warrant and CVR values are based on volatilities of $35 \%$ and $45 \%$, respectively. This analysis also assumes the Blockbuster merger is approved. Lazard estimated a value of $\$ 81.49$ if the Blockbuster merger was not approved.

${ }^{19}$ The warrant value is based on a volatility of $25 \%$.
} 
largely sophisticated institutions, including arbitragers) continue to have the ability to choose between the two proposals based on their views of value."20

Second, Lazard Freres valued both the first and second stages of the offers as if they were going to occur immediately. In fact, the cash portion of the winning offer would not be paid until the tender offer expired. This was to occur two weeks after a winner was declared. The non-common stock-based, non-cash portion of the winning offer would not be paid until shareholders approved the offer. This would be expected to occur three to four months after a winner was declared. ${ }^{21}$

In our calculations, we adjust for the two inaccuracies. First, we treat the offer values for each company as a function of the value of the bidder's stock conditional on winning, $A^{A}$ and $B^{B}$. Second, we discount the cash portion by $1 \%$ and the non-common stock-based, non-cash portion by $4 \%$ to reflect the fact that the shareholders would not receive the proceeds of the winning offer immediately. This assumes a discount rate of $1 \%$ per month. Our results are not sensitive to this assumption.

\section{B. Inferring Unobserved Stock Prices}

We can now solve explicitly for overpayment and relative synergies. As noted earlier, we assume that the actual values of Viacom and QVC on February 15 (time 3) when Viacom was declared the winner, $\mathrm{A}^{\mathrm{A}}(\$ 28)$ and $\mathrm{B}^{\mathrm{N}}(\$ 50.25)$, are the values the market expected from February 2 until February 14 (all potential time 2's). Similarly, we assume that the value of Viacom's offer conditional on Viacom winning, $\mathrm{O}^{\mathrm{A}}\left(\mathrm{A}^{\mathrm{A}}\right)$, equals Paramount's value of $\$ 77.00$ on February 15.

For February 2, we solve the following systems of equations for $\theta_{A}, A^{N}$, and $B^{B}:^{22}$

$$
\begin{array}{llll}
\text { Viacom B: } & 34.000=\theta_{\mathrm{A}} \mathrm{A}^{\mathrm{A}}+\left(1-\theta_{\mathrm{A}}\right) \mathrm{A}^{\mathrm{N}} & & =28 \theta_{\mathrm{A}}+\left(1-\theta_{\mathrm{A}}\right) \mathrm{A}^{\mathrm{N}} \\
\text { QVC: } & 45.875=\theta_{\mathrm{A}} \mathrm{B}^{\mathrm{N}}+\left(1-\theta_{\mathrm{A}}\right) \mathrm{B}^{\mathrm{B}} & & 50.25 \theta_{\mathrm{A}}+\left(1-\theta_{\mathrm{A}}\right) \mathrm{B}^{\mathrm{B}} \\
\text { Paramount: } & 78.000=\theta_{\mathrm{A}} \mathrm{O}^{\mathrm{A}}\left(\mathrm{A}^{\mathrm{A}}\right)+\left(1-\theta_{\mathrm{A}}\right) \mathrm{O}^{\mathrm{B}}\left(\mathrm{B}^{\mathrm{B}}\right) & & =\theta_{\mathrm{A}} 77.00+\left(1-\theta_{\mathrm{A}}\right) \mathrm{O}^{\mathrm{B}}\left(\mathrm{B}^{\mathrm{B}}\right)
\end{array}
$$

\footnotetext{
${ }^{20}$ Paramount Communications 13E3, May 25, 1994.

${ }^{21}$ In fact, the cash portion was paid on March 1, 1994, and the non-cash portion was paid on July 6, 1994.

${ }^{22}$ In this analysis, we use the volatilities used by Lazard Freres to value the warrants in the QVC and Viacom offers. We have repeated the analysis across a wide range of volatility assumptions. The results are qualitatively similar.
} 
We also solve the analogous system of equations for February 3 to February 14. Panel A of table 5 reports the results of this analysis, providing our estimates of $\theta_{A}, A^{N}$, and $B^{B}$ as well as actual closing share prices for Viacom, QVC, and Paramount from February 2 and February 15.

The pattern in panel A of table 5 suggests that even in this case, the assumptions necessary to derive information are not perfectly satisfied. On February 2, 3 and 9, we obtain the anomalous results that the market valued the QVC offer more highly than the Viacom offer yet imputed a higher probability to Viacom's offer succeeding. This is a function of the fact that Paramount's stock closed at a price greater than $\$ 77$ on these days. One explanation for this anomaly is that on those days, the market valued the Viacom offer somewhat more highly than the $\$ 77$ we have assumed.

The other anomalous results are for February 14 where we cannot obtain plausible estimates because the equations imply a negative value for QVC conditional on QVC winning. This result occurs (mechanically) because the likelihood of Viacom winning was very high on February 14, yet Paramount's stock price closed below $\$ 77.00$ at $\$ 76.125$.

Although the instability of these results is problematic, it is the case that the results are fairly stable and plausible from February 4 to February 11. The estimated values of Viacom and QVC conditional on QVC winning vary, respectively, from $\$ 41.98$ to $\$ 47.53$ and from $\$ 30.27$ to 34.65 . In the analysis in the following section, we use the average of these values of $\$ 44.62$ and $\$ 32.00$ over those six days.

In panel B, we make an alternative assumption that the market valued both the Viacom offer and the QVC offer at $\$ 77.00$ per share over the entire period from February 2 to February 15 . The rationale for this assumption is that the two offers were perceived to be very close in value by both the investment bankers and the market. If this assumption had truly been the case, Paramount's stock price would have remained at $\$ 77$ for the entire period. Nevertheless, we use this assumption for two reasons. First, except for February 2, 3, and 14, Paramount's actual closing price is within $\$ 0.50$ of $\$ 77.00$. Second, the resulting probabilities and estimated prices are smoother and non-anomalous from February 4 onward. 
Under the second set of assumptions, panel B estimates the value of QVC conditional on QVC winning as $\$ 33.07$. The estimated probability that Viacom would win increases monotonically from February 4 onward. The estimated value of Viacom conditional on QVC winning starts above $\$ 50$ on February 2 and 3, declines to the low $\$ 40$ range from February 4 to February 8, and then stays in the mid$\$ 40$ range from February 9 to February 14. In the analysis that follows, we use the average Viacom value from February 4 to February 14 of $\$ 44.13$.

In sum, the results in table 5 are mixed. The patterns are not consistent with the assumptions needed to make a definitive inference of overpayment and relative synergies. On the other hand, the estimates of the values of Viacom and QVC conditional on QVC winning are qualitatively similar over many days and under different assumptions. In the following section, we utilize these estimates to infer overpayment and relative synergies, acknowledging that they are potentially imperfect.

\section{Solving for Overpayment and Relative Synergies}

We can now use equations $1 \mathrm{~A}-1 \mathrm{E}$ to estimate the values of overpayment, relative synergy, and new information. Table 6 reports our results. Because they are qualitatively identical for each of the two sets of assumptions, we will discuss the results in panel A. Based on the results and assumptions in panel A of table 5, and the average values from February 4 to February 11, we assume: $\mathrm{A}^{\mathrm{N}}$, the value of Viacom $\mathrm{B}$ if QVC wins, equal to $\$ 44.62 ; \mathrm{A}^{\mathrm{A}}$, the value of Viacom $\mathrm{B}$ if Viacom wins, equals $\$ 28 ; \mathrm{B}^{\mathrm{N}}$, the value of QVC if Viacom wins, equals $\$ 50.25$; and $\mathrm{B}^{\mathrm{B}}$, the value of QVC if QVC wins, equals $\$ 32$.

The analysis also requires an assumption concerning the value of Viacom A. Viacom A traded at $\$ 34.25$ on February 15, corresponding to the value of Viacom A if Viacom wins. This is 1.22 times the value of Viacom B. To calculate the value of Viacom A if QVC wins, we multiply the estimate of Viacom B if QVC wins of $\$ 44.62$ to obtain $\$ 54.58 .^{23}$

\footnotetext{
${ }^{23}$ This implied premium for the A shares of $22 \%$ exceeds the premium for the A shares before the takeover contest began and during most of the contest. Our results are qualitatively identical assuming the average premium during the contest of $11 \%$.
} 
These estimates imply that both Viacom and QVC were willing to overpay by large amounts. Viacom overpaid by more than $\$ 2.0$ billion. Similarly, the estimates imply that QVC would also have overpaid by a smaller, but still substantial $\$ 688$ million.

Table 6 also shows that the market believed that the synergies of a QVC-Paramount combination substantially exceeded those of the Viacom-Paramount combination that occurred. While it is not possible to infer actual synergies, because we do not observe the stand-alone value of Paramount, $\mathrm{T}^{\mathrm{N}}$, it is possible to infer relative synergies. Table 6 reports that the expected QVC-Paramount synergies exceeded those expected in the Viacom-Paramount merger by over $\$ 1.4$ billion. Viacom won the takeover contest because it was willing to overpay (relative to market expectations) by much more than QVC was.

We can compare actual synergies only if we are willing to assume a standalone value for Paramount. One possibility is to assume that the standalone value of Paramount did not change over the course of the contest, remaining at the $\$ 55.875$ per share Paramount traded at on September 7,1993 . This seems plausible given that the shares of the four other most prominent companies in the industry - News Corp., Time Warner, Turner Broadcasting, and Walt Disney - were relatively stable over this period, increasing by an average of $2.4 \%$ from September 7 to February 15 . If we include (the new information revealed about) Viacom and QVC in the industry, the average return is $-5.3 \%$ for the six companies from September 7 to February 15. Under the assumption of no change in standalone value, the estimates imply synergies of $\$ 0.34$ billion with Viacom and $\$ 1.76$ billion with QVC. It appears, therefore, that the market assumed there were minor synergies to the Viacom combination and more substantial synergies to the QVC combination.

Finally, table 6 reports the new information revealed about both firms through the course of the takeover battle. Based on the stock prices on September 7, 1993, before the first takeover announcement, 
the stand-alone value of QVC has fallen by $\$ 481$ million. In comparison, Viacom's stand-alone value experienced a decline of more than $\$ 1.7$ billion. ${ }^{24}$

\section{Postscript}

In the three years following the acquisition, Viacom's stock price continued to perform poorly. From February 15, 1994 to February 28, 1997, Viacom B increased in value by $24 \%$. Over the same period, the S\&P increased by $71 \%$ and Viacom's three primary competitors (Disney, News Corp. and Time Warner) increased by $25 \%$. These results do not indicate that the market reacted inaccurately and do not support Redstone's view that Viacom and Paramount had great synergies.

When we extend the analysis to five years after the acquisition (to February 28, 1999), Viacom and Redstone do somewhat better. From February 15, 1994 to February 28, 1999, Viacom B increased in value by $211 \%$. Over that same period, the S\&P increased by $160 \%$ and Viacom's three primary competitors increased by $141 \%$. While these results are consistent with the market overestimating Viacom's overpayment and underestimating synergies, the industry returns still imply that Viacom overpaid by almost $\$ 1$ billion. $^{25}$

\section{E. Implications}

We find evidence of a stunning overpayment of more than $\$ 2.0$ billion for Viacom as well as almost $\$ 0.7$ billion for QVC. Sumner Redstone's willingness to overpay is striking given his ownership position in Viacom. Redstone owned 45.5 million of Viacom A shares and 46.6 million of Viacom B shares. Before the Blockbuster transaction, these holdings represented, $85 \%$ and $69 \%$, respectively, of the two classes of stock. Overall, therefore, Redstone controlled $76 \%$ of Viacom's cash flow rights and $85 \%$

\footnotetext{
24 If Paramount's stand-alone value, like those of Viacom and QVC, fell over this period, then the actual synergies would be greater than those calculated in the previous paragraph.

${ }^{25}$ This discounts Viacom's stock price in February 1999 by the industry return of $141 \%$ to get a Viacom B value of $\$ 36.67$ rather than $\$ 28.00$. This is almost $\$ 8$ less than the estimate of Viacom B without overpayment of $\$ 44.62$.
} 
of Viacom's voting rights (the B shares did not have any voting rights) when the takeover contest began. In this section, we consider different explanations or theories to explain these results.

We believe our results have two possible (and not mutually exclusive) interpretations. The first interpretation is that Redstone's beliefs were very different from those of the market. This particular contest and results are consistent with some of the arguments in Roll (1986). According to Roll (1986), acquirers overpay because they "mistakenly convince themselves that the market does not reflect the full economic value of the combined firm." Heaton (2002) and Malmendier and Tate (2002) make similar arguments in financing and investment contexts.

Redstone's actions as well as Diller's are consistent with this explanation. In Redstone's case, overconfidence / hubris also might logically have followed from the great success Viacom and he had enjoyed to that point. With a net worth of over $\$ 5$ billion, Redstone was one of the wealthiest men in the world. Redstone's earlier acquisition of Viacom in a leveraged buyout was the source of much of that wealth.

Roll's (1986) hubris hypothesis assumes that managers are acting in what they believe are the best interests of shareholders. It also is possible that managers obtain private, non-pecuniary benefits from control and acquisitions that do not benefit shareholders. The second interpretation, therefore, is that Redstone received large private (and non-pecuniary) benefits from the acquisition. Such managers may knowingly overpay if the private benefits of doing so outweigh the pecuniary costs. Theoretically, private benefit consumption decreases as managers own a larger share of a firm's cash flows (or equity). At some point, however, as management obtains effective voting control, managers may be able to increase private benefit consumption. ${ }^{26}$ Morck, Shleifer, Vishny (1988) describe this tradeoff and find evidence for it.

In the case of Paramount, Redstone's behavior is at least consistent with the arguments in Fama and Jensen (1983) and Morck et al. (1988). Redstone controlled a majority of the voting rights of Viacom

\footnotetext{
${ }^{26}$ E.g., see Fama and Jensen (1983).
} 
and, therefore, could choose to overpay if the private benefits were sufficient. Perhaps he wanted to be the "king of all media." It is worth emphasizing, however, that for private benefits to be the only explanation, Redstone must have obtained over $\$ 1.5$ billion in private or non-pecuniary benefits to justify his bid (given that he controlled $76 \%$ of Viacom's cash flow rights).

A third, but in this case, less convincing explanation is that given in Shleifer and Vishny (2001). In their model, companies with overvalued stock make acquisitions with that stock. Because the market does not completely recognize the overvaluation at the time of the acquisition, such bidders succeed in making acquisitions with overvalued stock. In the medium and long run, the bidder stock price declines as the market discovers the overvaluation.

Viacom's and Redstone's initial offer for Paramount is potentially consistent with the Shleifer and Vishny (2001) theory. The Viacom stock in Viacom's initial offer made up roughly $87 \%$ of the initial \$69.14 value for each Paramount share. At the time, Viacom enjoyed the highest market capitalization to operating cash flow ratio of any of its competitors. (See Kaplan (1994a)). Complicating this interpretation, however, is the fact that Viacom engaged in open market repurchases of B shares throughout the summer of 1993 - the period before the initial offer.

As we have seen, the initial offer was not successful. Instead, the stock and warrants in Viacom's final and successful offer comprised less than $14 \%$ of the total $\$ 77$ value for each Paramount share. Furthermore, Viacom's stock does not appear to have been particularly overvalued relative to Viacom's primary competitors over the ensuing three years nor relative to the entire market over the ensuing five years. In other words, it does not appear that Viacom and Redstone succeeded in issuing overvalued equity to pay for Paramount.

Finally, it is worth stressing that the results are not consistent with a classical agency or incentive problem. ${ }^{27}$ Given Redstone's large ownership stake in Viacom, it seems implausible that even greater equity incentives would have caused him to change his behavior.

\footnotetext{
${ }^{27}$ See Jensen and Meckling (1976).
} 
Overall, then, the most compelling explanations involve some combination of overconfidence and private benefits. Because the two are not mutually exclusive, it is not possible to distinguish between them. It is possible to conclude, however, that our analysis indicates that the combination of overconfidence and private benefits exceeded $\$ 1.5$ billion.

\section{Summary and Implications}

This paper analyzes the amount of information that can be extracted from stock prices around takeover contests. In the first part of the paper, we show that it is not possible in general to use target and bidder stock price movements to infer the market's estimates of synergies, bidder overpayment, and changes in bidder and target values. In two generic cases, however, we show that it is possible to use bidder and target stock prices to obtain market estimates of overpayments and synergies. One occurs when a sole bidder mounts an unsuccessful takeover attempt; the other occurs when the acquisition contest includes exactly two bidders.

In the second part of the paper, we illustrate one of these two generic cases through a study of the takeover contest for Paramount. Our calculations suggest that the market estimated that Viacom, the "winner" of the takeover battle, overpaid by more than $\$ 2$ billion when it agreed to purchase Paramount. This overpayment occurred despite the fact that Sumner Redstone, the CEO of Viacom, owned roughly two-thirds of Viacom. We view the results for Paramount and Viacom to be consistent with a combination overconfidence / hubris and private benefits for Redstone. The combination of overconfidence and private benefits exceeded $\$ 1.5$ billion.

The empirical portion of our paper also illuminates the theoretical work of Bebchuk and Hart (2001) who analyze the benefits and shortcomings of various mechanisms for replacing incumbent managers. As they point out, one of the benefits of tender offers is that they encourage the bidder to pass along some of its private benefits to existing shareholders in order to tempt them to accept their offer. Paramount's takeover auction did exactly this: it encouraged both bidders to increase the cash portions of their offers, signaling to existing shareholders that theirs was the deal with greater synergies. In the two 
weeks between the close of bidding and the declaration of the auction's winner, the market continually reset prices of the two bidders as market participants sought to simultaneously determine the probability of each firm winning, and consequently, other market participants' revised valuations of the bidders' offers. Thus, our case illustrates a situation in which market participants face difficulty in determining the value of an offer precisely because they do not know which firm will win the auction. 
Appendix A

Contingent Value Rights

The Contingent Value Rights (CVRs) can be viewed as Asian put spreads (where $\mathrm{S}_{\mathrm{V}}$ is the average stock pric e of Viacom B shares over a 20-day period one year after the merger). If the options expired in one year, then the payoff on the CVRs would be the difference between $\$ 48$ and the Viacom B price up to a max of $\$ 12$. This is:

$\mathrm{CVR}=\max \left[\min \left(48-\mathrm{S}_{\mathrm{V}}, 12\right), 0\right]$, or:

$\mathrm{CVR}=\max \left(48-\mathrm{S}_{\mathrm{V}}, 0\right)-\max \left(36-\mathrm{S}_{\mathrm{V}}, 0\right)$.

The CVRs were designed to signal Redstone's belief that substantial synergies existed between Paramount and Viacom. With low or no synergies, Viacom's stock could be expected to decline and the CVRs would be increasingly costly (up to $\$ 12$ per share). Alternatively, if the synergies were great, Viacom's stock could be expected to rise and the CVRs would be worthless.

The CVRs contained a delayed exercise option that complicates their valuation. The delayed exercise feature gave Viacom the right, at the end of the first year, to extend the CVRs for an additional year. But by delaying payment, the spread would widen to $\$ 14$, as the CVRs' payoff would become max $\left(51-S_{V}, 0\right)-\max \left(37-S_{V}, 0\right)$. This, in turn, could be delayed for another year, widening the spread further to $\$ 17$ with an upper-bound stock price of $\$ 55$.

The analysis that follows discusses the Monte Carlo valuation technique we used in the presence of embedded options. The Lazard-Frères (L-F) analysis assumes that it is never optimal for the issuer to exercise the CVRs embedded options, therefore L-F prices the CVR with Black-Scholes. This assumption is only valid when special conditions on the risk-free rate and volatilities are satisfied. ${ }^{28}$

\footnotetext{
${ }^{28}$ The condition is that at time $\mathrm{t}=1$, the payoff of the then-expiring $\$ 48$ put spread must, for all stock prices, be less than that of the one-year $\$ 51$ put spread. (In order for this payoff to be valued under Black-Scholes, an analogous condition must hold at $\mathrm{t}=2$.)
} 
We price the CVR taking into account that for certain realized stock prices at $\mathrm{t}=1,2$, it may be optimal for the issuer to exercise the rollover feature. ${ }^{29}$ Thus, the set of payoffs that can arise under certain contingencies can be written as follows:

\begin{tabular}{l|l|l}
\hline Time & Current Payoff & Rollover \\
\hline $\mathrm{t}=2$ & $\max \left(51-\mathrm{S}_{2}, 0\right)-\max \left(37-\mathrm{S}_{2}, 0\right)$ & $\mathrm{E}_{2}\left(\max \left(54-\mathrm{S}_{3}, 0\right)-\max \left(38-\mathrm{S}_{3}, 0\right)\right)$ \\
$\mathrm{t}=1$ & $\max \left(48-\mathrm{S}_{1}, 0\right)-\max \left(36-\mathrm{S}_{1}, 0\right)$ & $\mathrm{E}_{1}\left(\max \left(51-\mathrm{S}_{2}, 0\right)-\max \left(37-\mathrm{S}_{2}, 0\right)\right)$ \\
$\mathrm{t}=0$ & $\mathrm{E}_{0}\left(\max \left(48-\mathrm{S}_{1}, 0\right)-\max \left(36-\mathrm{S}_{1}, 0\right)\right)$ & -
\end{tabular}

To obtain a price for the CVRs, we proceed in three steps:

1. Using the current stock price, current risk-free rate, and historical volatility of Viacom, we simulate a distribution of future stock prices at $t=2$. Under this distribution, we calculate (pointwise) the payoffs to closing the position at $\mathrm{t}=2$ or rolling over the $\mathrm{CVR}$ for an additional year. We then obtain the minimum of these two alternatives and discount this inner payoff envelope back to $\mathrm{t}=1$ at the risk-free rate prevailing at $\mathrm{t}=1$.

2. At $t=1$ we compare the payoffs to closing out the position to those described above. If it was never optimal to exercise the embedded rollover option at $\mathrm{t}=2$, then we compare the BlackScholes price of a one-year, 14-pt. put spread at $\$ 54$ to closing out a 12-pt. put spread immediately. As before, the inner payoff envelope is obtained.

3. The inner payoff envelope calculated at $t=1$ is discounted back to $t=0$, the initiation date of the CVRs. The CVR price at $\mathrm{t}=0$ is then the mean value of this distribution of discounted payoffs. If it was never optimal to exercise the delay option at $t=1$, then this is replaced with the BlackScholes price of a 12-pt. put spread at $\$ 51$.

This process is repeated up to ten thousand times, and the arithmetic average is obtained over the entire set of draws. The key parameters in this exercise are the risk-free rate at each decision node and the stock price volatility for Viacom. Based on the zero-coupon yield curve prevailing on February 1, 1994, we inferred one-year forward rates at one and two years. For volatility, we used the value $45 \%$ assumed in the L-F analysis of the offer.

\footnotetext{
${ }^{29}$ Throughout the appendix, $\mathrm{t}=2$ denotes the time at which the second rollover option is evaluated by the CVR issuer, while $\mathrm{t}=1$ denotes the time at which the first $\mathrm{CVR}$ rollover is evaluated.
} 


\section{References}

Andrade, G., M. Mitchell and E. Stafford, 2001. New evidence and perspectives on mergers. Journal of Economic Perspectives 15, No. 2, 103-120.

Baghat, S. and D. Hirshleifer, 1997. Do takeovers create value? An intervention approach. Working paper, University of Michigan Graduate School of Business.

Bebchuk, L. and O. Hart, 2001. Takeover bids versus proxy fights in contests for corporate control. NBER working paper 8633 .

Bradley, M., A. Desai, and E.H. Kim, 1983. The rationale behind interfirm offers: Information or synergy? Journal of Financial Economics 11, 183-206.

Bradley, M., A. Desai, and E.H. Kim, 1988. Synergistic gains from corporate acquisitions and their division between the stockholders of target and acquiring firms. Journal of Financial Economics 21, 3-40.

Comment, R. and G. W. Schwert, 1995. Poison or placebo? Evidence on the deterrence and wealth effects of modern anti-takeover measures. Journal of Financial Economics 39, 3-43.

Eckbo, B. E., 1985. Mergers and the market concentration doctrine: Evidence from the capital market. Journal of Business 58, 325-349.

Eckbo, B. E., 1992. Mergers and the value of antitrust deterrence. Journal of Finance 47, 1005-1029.

Esty, B., 1998. The acquisition of Consolidated Rail Corporation (A and B), teaching note. Harvard Business School Case 5-298-087.

Fama, E. and M. Jensen, 1983. Separation of ownership and control. Journal of Law and Economics 26, $301-325$.

Franks, J., R. Harris, and S. Titman, 1991. The postmerger share-price performance of acquiring firms. Journal of Financial Economics 29, 81-96.

Fuller, K., J. Netter, And M. Stegemoller, 2002, What Do Returns to Acquiring Firms Tell Us? Evidence from Firms that Make Many Acquisitions, Journal of Finance 57, 1763-1793.

Grossman, S. and O. Hart, 1980. Takeover bids, the free rider problem, and the theory of the corporation. Bell Journal of Economics 11, 42-64.

Heaton, J.B., 2002. Managerial Optimism and Corporate Finance. Financial Management, Summer.

Jarrell, G. and A. Poulsen, 1987. Shark repellents and stock prices: The effects of antitakeover amendments since 1980. Journal of Financial Economics 19, 127-168.

Jensen, M. and W. Meckling, 1976. Theory of the firm: Managerial behavior, agency costs, and ownership structure. Journal of Financial Economics 3, 305-360.

Jensen, M. and R. Ruback, 1983. The market for corporate control: The scientific evidence. Journal of Financial Economics 11, 5-50.

Kaplan, S. N., 1994a. Paramount 1993. Case, University of Chicago Graduate School of Business.

Kaplan, S. N., 1994b. Paramount 1994. Case, University of Chicago Graduate School of Business.

Lang, L., R. Stulz, and R. Walkling, 1989. Tobin's q and the distribution of takeover gains. Journal of Financial Economics 24, 137-154.

Malmendier, U. and G. Tate, 2001. CEO Overconfidence and corporate investment. Working paper, Harvard 
University.

Mitchell, M., T. Pulvino, E. Stafford, 2001. Limited arbitrage in equity markets. Working paper, Harvard Business School.

Morck, R. A. Shleifer, and R.Vishny, 1988. Management ownership and market valuation: An empirical analysis. Journal of Financial Economics 20, 293-315.

Roll, R., 1986. The hubris hypothesis of corporate takeovers. Journal of Business 59, 97-216.

Schurman, S., 1999. Motives and value changes in corporate acquisitions: Evidence from anti-trust intervention. Ph.D. thesis, University of Chicago Graduate School of Business.

Shleifer, A. and R. Vishny, 2001. Stock market driven acquisitions. Working paper, University of Chicago.

Stulz, R., 1988. Managerial control of voting rights. Journal of Financial Economics 20, 25-54. 


\section{Table I}

Summary of takeover classification

This table summarizes the results of section 3 classifying takeovers based on how much information can be extracted from stock prices surrounding the takeover event. In Category I, investors know that one of the bidders will acquire the firm. In Category II, investors know that there is positive probability that the target will remain a stand-alone company. Category IIA occurs when the target is taken over. Category IIB occurs when it is not. "Comparative" synergies implies that while it is not possible to solve for the actual synergies in the acquisition, it is possible to see which bidder-target combination offered higher synergies.

\begin{tabular}{l|l|l|l|l}
\hline \# of & Type of & Category I & \multicolumn{2}{c}{ Category II } \\
\cline { 3 - 5 } bidders & Information & & Category IIA & Category IIB \\
\hline 1 & Synergies? & - & - & Yes \\
2 & Overpayments? & - & - & Yes \\
$>2$ & Synergies? & Comparative & - & - \\
& Overpayments? & Yes & - & - \\
& Synergies? & - & - & -
\end{tabular}


Table II

Time line of events in QVC, Viacom, and Paramount takeover contest

This table displays the sequence of alternating bids in the takeover contest for Paramount from September 1993 to February 1994. The two-step merger plans describe a price per share paid for the initial $51 \%$ of shares outstanding, and then conditional on the success of the tender offer, a plan for the remaining $49 \%$ of shares outstanding. The details surrounding the warrants of both firms, Viacom's convertible preferred stock, and its contingent value rights (CVRs) are explained in table 3.

\begin{tabular}{|c|c|c|}
\hline Date & Viacom & QVC \\
\hline September 13,1993 & $\begin{array}{l}\text { Initial Bid: } \\
\qquad 9.10 \text { in Cash } \\
.1 \text { Shares Viacom A } \\
.9 \text { Shares Viacom B } \\
\end{array}$ & \\
\hline September 20, 1993 & & $\begin{array}{l}\text { Initial Hostile Bid: } \\
\$ 30 \text { in Cash } \\
.893 \text { shares QVC Common }\end{array}$ \\
\hline October 20,1993 & $\begin{array}{l}\text { Viacom's Counter Offer: } \\
\text { First Step: } 50.1 \% \text { @ } \$ 80 / \text { share } \\
\text { Second Step: } .20 \text { shares Viacom A, } 1.083 \\
\text { shares Viacom B, } \\
.20 \text { shares Convertible Preferred }\end{array}$ & $\begin{array}{l}\text { First Tender Offer: } \\
\text { First Step: } 50.1 \% \text { Shares @ } \$ 80 \text {; } \\
\text { Second Step: } 1.43 \text { shares }\end{array}$ \\
\hline November 5, 1993 & $\begin{array}{l}\text { Amended Counter Offer: } \\
\text { First Step: } 50.1 \% \text { @ } \$ 85 / \text { share } \\
1.083 \text { shares Viacom B } \\
.30 \text { shares Convertible Preferred }\end{array}$ & \\
\hline November 12, 1993 & & $\begin{array}{l}\text { Second Tender Offer: } \\
\text { First Step: 50.1\% Shares @ \$90; } \\
\text { Second Step: } 1.43 \text { Shares, } \\
.32 \text { Convertible preferred } \\
\end{array}$ \\
\hline November 15,1993 & \multicolumn{2}{|l|}{ Paramount rejects QVC's Bid as too conditional } \\
\hline December 9, 1993 & \multicolumn{2}{|c|}{ Delaware Supreme Court Upholds Chancery Court Ruling Favoring QVC } \\
\hline December 20, 1993 & & $\begin{array}{l}\text { Third QVC Offer } \\
\text { First Step: } 50.1 \% \text { Shares @ \$92; } \\
\text { Second Step: } 1.43 \text { Shares, } \\
.32 \text { non-convertible preferred } \\
.3210 \text {-Yr. QVC Warrants }\end{array}$ \\
\hline January 7, 1994 & $\begin{array}{l}\text { Third Viacom Offer } \\
\text { First Step: } 50.1 \% @ \$ 105 ; \\
\text { Second Step: } .93 \text { shares Viacom B } \\
.30 \text { shares Convertible Preferred } \\
\end{array}$ & \\
\hline January 18, 1994 & $\begin{array}{l}\text { Fourth Viacom Offer } \\
\text { First Step: } 50.1 \% @ \$ 107 ; \\
\text { Second Step: } .93 \text { shares Viacom B } \\
.93 \text { Contingent Value Rights (see Table III } \\
.30 \text { shares Convertible Preferred } \\
.53 \text {-Yr. Warrants }\end{array}$ & \\
\hline February 1, 1994 & Final Bid: See table 3 & Final Bid: See table 3 \\
\hline
\end{tabular}


Table III

Final offers submitted by QVC and Viacom

This table describes the final offers for Paramount submitted by Viacom and QVC as of February 1, 1994.

\section{QVC}

Cash of $\$ 104$ per share for $50.1 \%$ of Paramount shares.

A securities package for the rest. For each of the remaining 49.9\% Paramount shares:

- $\quad 1.2361$ shares of QVC Common Stock.

- 0.2386 shares of QVC (non-convertible) Preferred Stock. Each share has \$50 liquidation value and pays an annual dividend of $6 \%$ or $\$ 3$ per share. In three years, the shares may be exchanged, at the option of QVC, for junior subordinated debentures.

- $\quad 0.32$ of a ten-year warrant to buy QVC shares with a strike price of $\$ 70.34$.

Cash of $\$ 107$ per share for $50.1 \%$ of shares

Viacom

A securities package for the rest. For each of the remaining $49.9 \%$ Paramount shares:

- 0.93065 of Viacom B Common Shares.

- 0.5 of a three-year Viacom B American Call Warrants with a strike price of $\$ 60$.

- $\quad 0.3$ of a five-year Viacom B American Call Warrants with a strike price of $\$ 70$.

- $\$ 17.50$ principal amount of a subordinated debenture with a coupon rate of $8 \%$ and a maturity of 12 years. The debentures were non-callable for 5 years assuming Viacom and Blockbuster merge. If the merger was not approved by Blockbuster shareholders, the subordinated debenture would be replaced with $\$ 17.50$ face value of Viacom preferred stock with a dividend yield of $5 \%$.

- $\quad 0.93065$ of a Contingent Value Right (CVR):

- After one year, Viacom can pay each CVR in cash or Viacom securities the difference between $\$ 48$ and the average closing prices of Viacom Class B stock over each twenty trading days over the 60 days prior to the one year maturity, up to $\$ 12$ per share. In other words, if the average price of Viacom Class B is less than $\$ 48$ per share, each CVR pays the lesser of ( $\$ 48-$ Via B) or $\$ 12$.

- At the one year maturity, Viacom can, if it chooses, extend the CVR an addition year (for a total maturity of two years). If Viacom does so, it must pay the difference between $\$ 51$ (not \$48) and the average closing prices up to a maximum of \$14 (not \$12) per share. Finally at the two year maturity, Viacom can extend the CVR for one last year, after which Viacom must pay the difference between $\$ 55$ and the average closing prices up to a maximum of $\$ 17$ per share. 
Table IV

Value of initial and final bids using prevailing stock prices

Value of Viacom offers on September 12, 1993 and on February 3, 1994, and QVC offers on September 20, 1993 and February 3, 1994 using closing stock prices on the respective dates. The value of the final Viacom offer assumes the Blockbuster merger occurs. Sources: Lazard Freres presentation to Paramount Board in Paramount Communications 13E3, May 25, 1994.

Viacom's Initial Offer, September 12, 1993

\begin{tabular}{|c|c|}
\hline $\begin{array}{l}\$ 9.10 \text { in cash } \\
0.1 \text { shares of Viacom A } \\
0.9 \text { shares of Viacom B }\end{array}$ & $\begin{array}{l}\$ 9.10 \\
\$ 6.60 \\
\$ 53.44\end{array}$ \\
\hline & $\$ 69.14$ \\
\hline
\end{tabular}

QVC's Hostile Bid, September 20th, 1993

\begin{tabular}{lc|l}
\hline$\$ 30.00$ in cash & $\$ 30.00$ \\
.893 QVC shares & Total & $\$ 50.01$ \\
\hline
\end{tabular}

Viacom's Final Offer: February 3, 1994

\begin{tabular}{l|c|c|c|c}
\hline Security & Value & Ratio & Amount & Per Share \\
\hline Cash & 107.00 & 0.501 & 1.000 & 53.61 \\
Subordinated Debt & 0.96 & 0.499 & 17.50 & 8.41 \\
CVR & 8.33 & 0.499 & 0.931 & 3.87 \\
Warrant - 3 year & 3.28 & 0.499 & 0.500 & 0.82 \\
Warrant - 5 year & 5.48 & 0.499 & 0.300 & 0.82 \\
Common & 34.00 & 0.499 & $0.931 \quad$ Total & 83.31 \\
\hline \multicolumn{5}{c}{} \\
QVC's Final Offer: February 3,1994 & 15.79 \\
\hline Cash & 104.00 & 0.501 & 52.10 \\
Warrant - 10 year & 31.53 & 0.499 & 0.239 & 3.76 \\
Common & 15.97 & 0.499 & 0.320 & 2.55 \\
\hline
\end{tabular}




\section{Table V}

Time series of Viacom stock prices, QVC stock prices, and implied Viacom success probabilities

This table uses trading prices for Viacom and QVC to infer the market's estimate of Viacom's success probability, the value of Viacom in QVC wins, and the value of QVC if QVC wins. The calculations assume that the closing prices on February 15, 1994 for Viacom and QVC ( $\$ 28$ and $\$ 50.25$, respectively) proxy for the market's expectation of these values at each date from February 2 to February 14. Similarly, the calculations also assume that the value of the Viacom offer for Paramount equals the value of Paramount on February $15-\$ 77$ - from February 2 to February 14 . In panel A, this creates a system of three equations and three unknowns (Equation 5 in the text) that are solved for each date. In panel B, the value of the QVC offer is fixed at $\$ 77.00$ which fixes the value of QVC if QVC wins at $\$ 33.07$ per share. This creates a system of two equations in two unknowns that are solved for each date.

\begin{tabular}{|c|c|c|c|c|c|c|c|c|c|c|c|c|c|}
\hline \multirow[b]{3}{*}{ Date } & & & & \multicolumn{5}{|l|}{ Panel A: } & \multicolumn{5}{|l|}{ Panel B: } \\
\hline & \multicolumn{3}{|c|}{ Actual Prices: } & \multirow{2}{*}{$\begin{array}{r}\text { Prob. } \\
\text { Viacom } \\
\text { wins }\end{array}$} & \multirow{2}{*}{$\begin{array}{r}\text { Viacom B } \\
\text { if QVC } \\
\text { wins }\end{array}$} & \multirow{2}{*}{$\begin{array}{r}\text { QVC if } \\
\text { QVC } \\
\text { wins }\end{array}$} & \multirow{2}{*}{$\begin{array}{r}\text { Value } \\
\text { Viacom } \\
\text { Offer }\end{array}$} & \multirow{2}{*}{$\begin{array}{c}\text { Value } \\
\text { QVC } \\
\text { Offer }\end{array}$} & \multirow{2}{*}{$\begin{array}{r}\text { Prob. } \\
\text { Viacom } \\
\text { wins } \\
\end{array}$} & \multirow{2}{*}{$\begin{array}{r}\text { Viacom B } \\
\text { if QVC } \\
\text { wins }\end{array}$} & \multirow{2}{*}{$\begin{array}{r}\mathrm{QVC} \text { if } \\
\mathrm{QVC} \\
\text { wins }\end{array}$} & \multirow{2}{*}{$\begin{array}{l}\text { Value } \\
\text { Viacom } \\
\text { Offer }\end{array}$} & \multirow{2}{*}{$\begin{array}{l}\text { Value } \\
\text { QVC } \\
\text { Offer }\end{array}$} \\
\hline & QVC & Viacom B & $\begin{array}{c}\text { Para- } \\
\text { mount }\end{array}$ & & & & & & & & & & \\
\hline Feb. 02 & $\$ 46.750$ & $\$ 33.500$ & $\$ 78.000$ & 0.715 & $\$ 47.31$ & $\$ 37.96$ & $\$ 77.00$ & $\$ 80.49$ & 0.796 & $\$ 55.00$ & $\$ 33.07$ & $\$ 77.00$ & $\$ 77.00$ \\
\hline Feb. 03 & $\$ 45.875$ & $\$ 34.000$ & $\$ 78.125$ & 0.654 & $\$ 45.34$ & $\$ 37.61$ & $\$ 77.00$ & $\$ 80.23$ & 0.745 & $\$ 51.56$ & $\$ 33.07$ & $\$ 77.00$ & $\$ 77.00$ \\
\hline Feb. 04 & $\$ 43.875$ & $\$ 32.875$ & $\$ 76.500$ & 0.671 & $\$ 42.80$ & $\$ 30.89$ & $\$ 77.00$ & $\$ 75.46$ & 0.629 & $\$ 41.14$ & $\$ 33.07$ & $\$ 77.00$ & $\$ 77.00$ \\
\hline Feb. 07 & $\$ 45.125$ & $\$ 32.375$ & $\$ 76.500$ & 0.744 & $\$ 45.06$ & $\$ 30.27$ & $\$ 77.00$ & $\$ 75.03$ & 0.702 & $\$ 42.67$ & $\$ 33.07$ & $\$ 77.00$ & $\$ 77.00$ \\
\hline Feb. 08 & $\$ 45.125$ & $\$ 31.875$ & $\$ 76.750$ & 0.723 & $\$ 41.98$ & $\$ 31.76$ & $\$ 77.00$ & $\$ 76.08$ & 0.702 & $\$ 40.99$ & $\$ 33.07$ & $\$ 77.00$ & $\$ 77.00$ \\
\hline Feb. 09 & $\$ 45.125$ & $\$ 33.250$ & $\$ 77.375$ & 0.671 & $\$ 43.98$ & $\$ 34.65$ & $\$ 77.00$ & $\$ 78.12$ & 0.702 & $\$ 45.60$ & $\$ 33.07$ & $\$ 77.00$ & $\$ 77.00$ \\
\hline Feb. 10 & $\$ 45.625$ & $\$ 32.750$ & $\$ 76.875$ & 0.742 & $\$ 46.38$ & $\$ 32.35$ & $\$ 77.00$ & $\$ 76.49$ & 0.731 & $\$ 45.64$ & $\$ 33.07$ & $\$ 77.00$ & $\$ 77.00$ \\
\hline Feb. 11 & $\$ 46.875$ & $\$ 31.625$ & $\$ 76.875$ & 0.814 & $\$ 47.53$ & $\$ 32.06$ & $\$ 77.00$ & $\$ 76.29$ & 0.804 & $\$ 46.45$ & $\$ 33.07$ & $\$ 77.00$ & $\$ 77.00$ \\
\hline Feb. 14 & $\$ 48.500$ & $\$ 29.875$ & $\$ 76.125$ & N.A. & N.A. & $<0.00$ & $\$ 77.00$ & N.A. & 0.898 & $\$ 46.41$ & $\$ 33.07$ & $\$ 77.00$ & $\$ 77.00$ \\
\hline Feb. 15 & $\$ 50.250$ & $\$ 28.000$ & $\$ 77.000$ & 1.00 & N.A. & N.A. & $\$ 77.00$ & N.A. & 1.000 & N.A. & N.A. & $\$ 77.00$ & N.A. \\
\hline
\end{tabular}


Table VI

Analysis of overpayments and synergies

Estimates of overpayments and synergies in the Viacom - QVC - Paramount takeover contest. QVC share price had QVC won and Viacom Class B share price had Viacom lost are the average of their respective values from February 4 to February 11, 1994 reported in table 5 for panel A and from February 4 to February 14 for panel B. Viacom Class A share price had Viacom lost is calculated to equal 1.22 times the Viacom Class B share price, the same ratio as 34.25 to 28.00 .

$T^{N}$ denotes the value of Paramount (the target) as a stand-alone firm, i.e. if no acquisition had occurred. We also report total synergies assuming that

Paramount's value, $T^{N}$, is equal to its value of $\$ 55.875$ per share on September 7,1993 . Total values of overpayments and relative synergies are based on $120 \mathrm{M}$ shares outstanding of Viacom stock (67M class B, 53M class A), 120M shares outstanding of Paramount stock, and 37.7M shares outstanding of QVC stock. New information revealed for each firm is calculated using September 7, 1993 prices for Viacom Class A of \$66.25 per share, Viacom Class B of \$59.25 per share, and QVC of $\$ 63.00$.

\begin{tabular}{|c|c|c|c|c|}
\hline & & Panel A: & \multicolumn{2}{|c|}{ Panel B: } \\
\hline \multicolumn{5}{|c|}{ QVC } \\
\hline$(1)$ & QVC Share Price, Had It Won & $\$ 32.00$ & \multicolumn{2}{|c|}{$\$ 33.07$} \\
\hline$(2)$ & Prevailing Share Price, 2/15/94, Having Lost & $\$ 50.25$ & \multicolumn{2}{|c|}{$\$ 50.25$} \\
\hline (3) & Offer Value, at $\$ 32.00$ per share & $\$ 76.24$ & \multicolumn{2}{|c|}{$\$ 77.00$} \\
\hline (4) & Overpayment: [(2)-(1)] x $37.7 \mathrm{M}$ & $\$ 688 \mathrm{M}$ & \multicolumn{2}{|c|}{$\$ 648 \mathrm{M}$} \\
\hline$(5)$ & Total QVC-Paramount Synergies: (3) x $120 \mathrm{M}-(4)-\boldsymbol{T}^{\mathrm{N}}$ & $\$ 8,461 \mathrm{M}-\boldsymbol{T}^{\mathrm{V}}$ & \multicolumn{2}{|c|}{$\$ 8,592 \mathrm{M}-\boldsymbol{T}^{\mathrm{N}}$} \\
\hline$\left(5^{\prime}\right)$ & Total QVC-Paramount Synergies if $T^{N}=T^{0}$ & $\$ 1,756 \mathrm{M}$ & \multicolumn{2}{|c|}{$\$ 1,887 \mathrm{M}$} \\
\hline$(6)$ & $\begin{array}{l}\text { New Information Revealed Since Sept. 7: } \\
{[(2)-\$ 63.0] \text { x } 37.7 \mathrm{M}}\end{array}$ & $-\$ 481 \mathrm{M}$ & \multicolumn{2}{|c|}{$-\$ 481 \mathrm{M}$} \\
\hline \multicolumn{5}{|c|}{ Viacom } \\
\hline & & Class A & Class A & Class B \\
\hline$(1)$ & Prevailing Share Price, 2/15/94, Having Won & $\$ 28.00$ & $\$ 34.25$ & $\$ 28.00$ \\
\hline$(2)$ & Viacom Share Price, Had It Lost & $\$ 44.62$ & $\$ 53.98$ & $\$ 44.13$ \\
\hline (3) & Offer Value, at $\$ 28.00$ per share & $\$ 77.00$ & \multicolumn{2}{|c|}{$\$ 77.00$} \\
\hline (4) & $\begin{array}{l}\text { Overpayment: } \\
{[(2 \mathrm{~A})-(1 \mathrm{~A})] \times(53 \mathrm{M} \mathrm{A})+[(2 \mathrm{~B})-(1 \mathrm{~B})] \times(67 \mathrm{M} \mathrm{B})}\end{array}$ & $\$ 2,191 \mathrm{M}$ & \multicolumn{2}{|c|}{$\$ 2,126 \mathrm{M}$} \\
\hline$(5)$ & Total Viacom Paramount Synergies: (3) x 120M-(4) - $\boldsymbol{T}^{\mathrm{N}}$ & $\$ 7,049 \mathrm{M}-\boldsymbol{T}^{\mathrm{N}}$ & \multicolumn{2}{|c|}{$\$ 7,113 \mathrm{M}-\boldsymbol{T}^{\mathrm{N}}$} \\
\hline$\left(5^{\prime}\right)$ & Total Viacom-Paramount Synergies if $T^{N}=T^{0}$ & $\$ 344 \mathrm{M}$ & \multicolumn{2}{|c|}{$\$ 409 \mathrm{M}$} \\
\hline$(6)$ & $\begin{array}{l}\text { New Information Revealed Since Sept. 7: } \\
{[(2 \mathrm{~A})-\$ 66.25] \text { x 53M A + [(2B) - \$59.25] x } 67 \mathrm{M} \mathrm{B}}\end{array}$ & $-\$ 1,599 \mathrm{M}$ & \multicolumn{2}{|c|}{$-\$ 1,663 \mathrm{M}$} \\
\hline
\end{tabular}

